\title{
Trade Credit and the Bank Lending Channel
}

\author{
Jeffrey H. Nilsen ${ }^{1}$ \\ Studienzentrum Gerzensee \\ jhn@szgerzensee.ch
}

August, 1999

\begin{abstract}
The bank lending channel theory posits that during monetary contractions banks restrict some firms' loans, thus reducing their desired investment independently of interest rates. Previous research finds small firms reduce, while large firms accelerate, loan growth. We find that small firms increase trade credit, a substitute credit, indicating a strong loan demand. It supports the bank lending channel: they do not voluntarily cut bank loans since they increase a less-desirable alternative. Using trade credit is propitious since unlike commercial paper (investigated by previous researchers), it is widely used by the small firms suffering the loan decline. Surprisingly, we also find large firms increase trade credit, a puzzle since they are typically assumed to have wide access to other credit. Using individual firm data, we find the reasons large firms use trade credit are financial in nature: those without a bond rating increase trade credit (i.e. without access to open market credit). As relatively few firms have this mark of quality, it implies that more firms are affected by credit constraints than previously believed.
\end{abstract}

JEL Codes: $\quad$ E44, E51, E52, E65

Keywords: Bank Lending Channel, Credit Channel, Manufacturing Firms, Monetary Policy, Trade Credit

I thank the editor, Paul Evans, as well as three anonymous referees for criticism leading to substantial improvements. I am very grateful for the guidance by Ben Bernanke and Larry Ball during the dissertation at Princeton University on which this paper is based. The work continued during my appointments at CERGE-EI (Prague) and the Copenhagen Business School. Ibenefitted from comments by Joe Beauleau, Philippe Bacchetta, Arup Daripa, Simon Gilchrist, Uli Hege, Martin Hess, Cara Lown, Robin Lumsdaine, Lester Taylor, David Wilcox, and seminar participants at Princeton University, IAS (Vienna), J.W. von Goethe Universität (Frankfurt), the Bank of England, the Norwegian Central Bank, CERGE-EI, the Swiss National Bank, and the EEA Summer School (Helsinki). I thank Simon Gilchrist and Egon Zakrajsek for kindly providing the QFR data. I am responsible for any remaining errors. 


\section{Introduction:}

Opinion remains divided about how credit market imperfections influence the transmission of monetary policy to the real economy (see surveys by Bernanke (1993) and Kashyap and Stein (1994)). Many economists believe only the "money channel" (it posits that the cost of capital is the means by which monetary shocks are transmitted to the real economy) is important, in particular, that the financial sector is irrelevant. The money channel view holds that when the central bank reduces reserves, higher costs of funds induce banks to reduce their demand deposits (a liability). If prices are sticky, this short-run decline in real money balances raises real interest rates to slow interest-sensitive spending and thus economic activity (see Mishkin's (1998) textbook summary of transmission channels).

"Credit channel" proponents believe that credit also plays an important part in the propagation of monetary shocks into the real economy (see, e.g. Bernanke and Gertler, 1995). The "broad credit channel" branch of the literature stresses that some firms are subject to an external finance premium, defined as the cost spread between a firm's external funds (bonds, loans, and equity) and its internal funds (retained earnings). According to this theory, the higher risk increases information problems during a recession, thus increasing the affected firms' external finance premium. This then amplifies the policy-induced impact of market rates on firms. Firms without access to open market credit are more subject to information problems and thus this "financial accelerator".

Another credit channel is the "bank lending channel". Many of its proponents e.g. Bernanke and Blinder (1988), Kashyap and Stein (1995), assert that banks' asset decisions also play an important role in monetary policy independently of the cost of capital. The theory predicts that a reduction in reserves induces banks to scale back lending activities. And this disproportionately affects a class of firms that cannot readily

switch to other funds, those without access to credit markets. Small manufacturers, for instance, may be more dependent on banks than other firms, and without alternative financing, they may be forced to limit desired investment (or current production) for a given market interest rate.

The bank lending channel is the most disputed transmission mechanism in recent empirical research. Romer and Romer (1989) argue that loans do not play an important role since they find that a policy tightening initially impacts interest rates through deposits, not loans. Bernanke and Blinder (1992), though, find that policy shocks affect bank portfolios systematically, which money channel theories 
cannot explain ${ }^{2}$. Moreover, they find banks' securities is the type of asset responsible for the immediate post-tightening decline in their balance sheets and that real activity sags later, at about the same time as the reduction in loans. It is, however, difficult to disentangle whether firms are affected by the slow-down in activity (inducing a reduction in credit demand) or from a loan supply reduction (as predicted by the bank lending channel). Kashyap, Stein, and Wilcox (1993) ingeniously solve this identification problem using commercial paper. They show firms issue more of this substitute credit during monetary contractions, thus suggesting that firms' lower activity is due to a loan supply reduction and not that their loan demand is reduced by the activity slowdown. Oliner and Rudebusch (1996), though, discovered an error in composition in the Kashyap et al analysis; since only large firms issue commercial paper, its rise cannot inform about small firms, those shown by Gertler and Gilchrist (1994) to suffer the loan growth reductions. Gertler and Gilchrist find that large firms actually accelerated bank lending. Thus, the findings to date still allow interpretation of small firms' bank loan reduction as due to lower demand from slower activity.

We make a simple test of the bank lending channel using a substitute credit following Kashyap, et al, but with a substitute also available to the firms suffering the lending decline. Trade credit (TC), is a loan a supplier provides to its customers in conjunction with product sales. TC is available to small firms yet its high cost (see part II) makes it unattractive for short periods beyond its intended duration. Small firms do utilize TC: those small firms surveyed by Davey (1989) seem to favor it second after bank loans. Our test exploits firms' reluctance to switch from loans to an imperfect substitute: since TC is small firms' only alternative, their higher TC would identify diminished loan growth during tight money as due to restricted loan supply. Accordingly at times of tight monetary policy, if the bank lending channel theory is correct, we should see small firms increasing TC and large firms, with assumed alternative credit, should avoid TC.

We find that those firms usually believed to be credit constrained, small firms, use greater amounts of TC during monetary contractions, behavior which identifies a steady demand for credit. This evidence supports the bank lending channel as small firms are switching from loans to TC, their only practical alternative. Surprisingly, we find that large firms also increase TC, indeed to a greater extent than small firms. This is puzzling indeed since large firms are often viewed as older, better established firms and thus less prone to information problems blocking small firms from open market credit. Banks view the large firms as better risks for the same reasons.

We thus investigate why it is that large firms, with supposed untapped sources of inexpensive funds,

${ }^{2}$ Money channel theories view all bank assets as perfect substitutes. It implies banks' asset composition should change only randomly following a monetary shock. 
turn to an expensive substitute at times of tight monetary policy. It may be that their rising unplanned inventories (see Kashyap, Lamont, and Stein (1992)) exhaust their low cost funds sources so they too suffer acute funding problems. ${ }^{3}$ To investigate this issue, we split a group of large manufacturing firms by criteria likely to influence their use of TC. Using firms' bond ratings, the direct measure of access to credit markets first used in empirical studies by Whited (1992), we find it is indeed non-rated firms that increase TC. Rated firms, on the other hand, use more loans. In other words, only those large firms with a recognized credit standing are able to avoid TC; these are the firms banks prefer to lend to, a "flight to quality" as suggested by Bernanke, Gertler and Gilchrist (1994). It suggests that the reason large firms increase TC in the earlier small-large firm data is that some of them are also credit constrained. So largeness, per se, is only an imperfect indicator of credit quality and credit constraints involve a wider set of firms than is implied by perfect credit markets.

Previous research has studied TC for evidence on credit market imperfections within business cycles. Jaffee (1971) and Duca (1986) find evidence to support Meltzer's (1960) redistribution hypothesis which posits that during tight money periods, more-liquid (large) firms pass funds via TC (their accounts receivable) to less-liquid (small) customers (see discussion in part II). More recently, Gertler and Gilchrist (1993) and Oliner and Rudebusch (1996) have found that TC does not rise during monetary contractions. Ramey (1992, p182), however, describes other aggregate data, and observes "peaks in [TC] ... occurred during credit crunches...”. Yet this recent research examines a simple stock of TC, neglecting to control for TC's strong relationship with transactions (see discussion in part II).

The remainder of the paper is organized as follows: in section II, we examine the motives for firms to utilize TC. We will emphasize the use of TC during monetary policy contractions. In section III we report results from the test strategy of examining small and large manufacturing firms in the U.S. These firm types are frequently used as stereotypes corresponding to firms with and without access to financial markets. In section IV, we reexamine TC using a database which provides a better indicator of capital market access than the earlier data. Finally, we conclude in section V.

${ }^{3}$ Another possibility we explore briefly in section IV is provided by Brechling and Lipsey (1963), who suggest that large customers exploit their monopsony power and e.g. threaten to purchase inputs from other suppliers. In ignoring the small supplier's TC terms, the large customer forces its small suppliers to provide TC "cheaply". 


\section{Why Firms Use Trade Credit}

Trade credit is a short-term loan a supplier provides to its customer upon a purchase of its product. It is a significant part of U.S. manufacturing firms' balance sheets: the share of accounts payable (AP hereafter) in total liabilities is $13 \%$ (QFR, 1990). And importantly, it is frequently used by small firms: Cole and Wolken (1995) summarize the 1993 National Survey of Small Business Finances by noting TC is used by $61 \%$ of small businesses, "... a rate that exceeded the use of all other financial services except checking". Davey's survey shows small firms ${ }^{4}$ choose TC after loans as credit source (bank loans were noted by $90 \%$, TC by $58 \%$ ). In contrast, large firms preferred commercial paper (73\%), then loans (53\%) and finally TC (31\%).

Two distinct actors take decisions involving TC at two distinct times in the period around the product sale. The supplier decides whether to offer a customer TC during deliberations over the sales transaction. A critical influence in this decision is his relationship with the customer. Then the customer decides, given that she is creditworthy and has bought the good, to repay or delay when repayment is due. The first decision concerns the transactions motive of TC - the supplier provides a credit service to the customer which reduces the customer's transactions costs of using cash. The second decision involves the finance motive. We thus note the transformation of TC from a substitute payment medium (a preferred substitute for cash) to a substitute finance medium (an unattractive substitute for bank loans). TC's substitution for cash is shortlived since of course the customer must eventually repay using e.g. demand deposits. We find the finance motive of TC as a useful indicator of credit constraints, but must control for the transactions motive.

The following theoretical section summarizes the behavior of manufacturers and their role in the use of TC at various periods in the business cycle. We first describe the firms' choice of TC at the time of the sales decision, the transactions motive (which we will usually call "transactions TC"). The following section reviews the finance motive (which we will usually call "finance TC"), the idea that firms more frequently delay repayment to suppliers when they lack funds and have few alternative funds sources. We introduce the logic underlying our selection of AP/Sales as indicator of the finance motive and show that the ratio is unchanged by transactions influences. Finally, part II.C. summarizes the influences in AP/Sales at monetary contractions, when firms are most likely to face binding credit constraints, and describes our use of AP/Sales as test of the bank lending channel.

\footnotetext{
${ }^{4}$ Davey defined small firms as those having less than $\$ 500$ million in sales.
} 


\section{II.A. Transactions Motive:}

The transactions motive is the simple idea that TC provides transactions services to firms. As a customer purchases more products, more TC allows higher cost savings. This is the basis for a direct relation between TC and the amount of a firm's transactions. Thus, when we observe sales rising, we expect TC to rise. Obviously, this motive explains a major part of the level of AP, and importantly whenever sales fall it predicts that AP falls.

Several theories investigate this motive for firms' use of TC. Schwartz (1974) explains that the customer benefits since TC simplifies cash management. In a world of e.g. uncertain deliveries, TC, as a separator between the exchanges of cash and goods, smoothes the uncertainty of a customer's future outlays. In Ferris' (1981) model, the customer passes on some part of TC's cost savings to its supplier-partner as they jointly coordinate uncertainly-timed payments. Transactions use of TC thus allows firms to reduce their precautionary cash holdings and instead hold interest-earning assets.

A model based on relationships likely characterizes a large if not defining part of TC use in the economy. A large literature investigates bank-firm relationships (see, e.g. Petersen and Rajan, 1994, 1995); customer relationships play a yet greater role in TC offers since by definition credit provision is not the supplier's specialty. It suggests the supplier offers TC to its customers based on levels of trust: whether she is an existing credit, existing non-credit, or new customer (see discussion in part II.B below). The supplier offers TC with an expectation the invoice will be paid on time, and often includes a discount incentivizing early repayment (see discussion on the customer's motive to delay in part II.B below). The TC offer reflects the transactions motive as each sale dollar links the customer to cost savings in delayed cash use ${ }^{5}$.

The Quarterly Financial Reports of Manufacturing Firms (QFR hereafter) data confirms the strong transactions-based relation: TC and sales show an almost proportional relationship; large manufacturing firms maintain AP to sales ratios ranging between 19-28\%, while small firms' ratio fluctuates within an even

\footnotetext{
${ }^{5}$ It is related to Nadiri's (1969) neoclassical model which posits a firm that manipulates TC (like advertising) to maximize sales revenue. The model highlights the beauty of AR as a sales repayment incentive device: the discount helps induce purchase, while high implicit rates convincingly remind customers to repay on time.

${ }^{6}$ Ferris' transactions motive also posits that firms increase TC with higher interest rates, but given sales. Sales fall with tight money, and then the model predicts TC only ambiguously.
} 
narrower band of 23\%-29\% for the 32 years of QFR data (Figure 1$)^{7}$.

\section{II.B. Finance Motive ${ }^{8}$ :}

"The Sovereign can leave bills unpaid - for a time - although high rates of interest quickly find their way into prices paid by the royal household."

A Financial History of Western Europe Kindleberger (1993, p. 157)

Customers sensibly like transactions TC: it lets them purchase inputs without putting cash "up front".

But finance TC's characteristics imply it is a highly

unattractive substitute for bank loans. First, it is tied to the purchase of goods, while loans may be unrestricted. Further, the supplier requires TC repayment typically within 30 days, while loans are usually longer-term. Finally, the customer's TC credit provider is its supplier and not an independent finance specialist, so a customer faces significant late payment

\section{Figure 2}

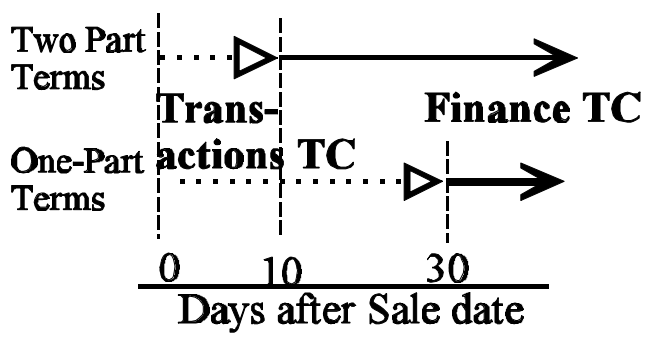
penalties including implicit costs of damaging a critical long-term relationship as well as explicit and significant pecuniary penalties (Petersen and Rajan, 1994). Figure 2 shows the distinction between transactions TC and finance TC.

One indicator of finance TC's unattractiveness is the lost earnings when customers ignore the early repayment discount. The most common payment plan is "2/10, net 30"9 $\mathrm{Ng}$ et al (1999), by which a customer takes a $2 \%$ discount on the purchase price if she repays within 10 days; otherwise she repays in full

${ }^{7}$ Figure 1 shows large firms AP/Sales converge to small firms', perhaps a consequence of QFR data construction (small firms migrate to larger categories over time due to the nominal asset criterion). See the Appendix and especially Figure A.4 to compare large firms' AP/Sales in the QFR and Compustat. We are confident detrending extracts valid business cycle information, but are uncomfortable in using it for long-term analysis (e.g. cointegration).

${ }^{8}$ The finance motive implies credit market imperfections, since perfect markets would allow the customer to obtain lower-cost funds. The transactions motive does not require imperfections since firms rationally cut costs; e.g. firms with payment fluctuations save via TC vs. separate overdraft facilities.

${ }^{9}$ Payment terms differ among industries. Ng et al found one-part terms also common; e.g. a simple net payment, where the customer has e.g. 30 days to settle the bill. 
within 30 days. The customer granted TC at purchase thus faces a simple financial decision at the discount date (the 10 day deadline). She delays the $98 \%$ list payment if the returns from investing it exceed the extra $2 \%$ to be repaid in 20 days (this is over $40 \%$ at annual rates). ${ }^{10}$ The customer's incentive to repay at discount is obviously strong since very few alternative instruments offer such a high yield. Petersen and Rajan (1994), for example, conservatively estimate TC's cost in a cross section of small firms and find it more expensive than $99.8 \%$ of the loans in the sample.

The finance motive focuses on the customer as initiator of the post-purchase "credit extension". A lack of funds can compel the customer to delay TC repayment and so abandon the very attractive interest rates offered by the supplier's discount incentive. While TC is an unattractive substitute for loans, it lies "readily at hand", credit a customer conveniently invokes if facing reduced bank credit; she merely delays repaying her bill, lengthening TC duration and thus "extending" credit to herself. Since suppliers typically respond passively ( $\mathrm{Ng}$, et al 1999), we may observe AP rising for this reason during say, monetary contractions. In "requesting" this credit, customers reveal they are willing to pay very high interest rates indeed for the use of short term funds.

We cannot use the variable AP to indicate the finance motive due to the strong confounding effect of the transactions motive of TC, discussed in part II.A. We fully expect a reduction in sales transactions at the onset of a tight money episode to induce a reduction in AP, so we control for transactions by using AP/Sales. Table 1 shows that AP/Sales, our indicator of the finance motive, is not systematically affected by any likely TC offer policy and reaction; i.e. the ratio is robust to the transactions motive. When one considers also evidence in $\mathrm{Ng}$, et al (1999), who report a survey of nearly 1,000 suppliers that "We find little willingness to vary [TC] terms either in lieu of product price changes or in response to a change in prevailing interest rates ... trade credit terms are stable over time." it strongly supports the insensitivity of supplier's role to the business cycle: once he decides to extend TC to a particular customer, it continues the practice as a matter of policy $^{11}$.

$$
{ }^{10} \text { The calculation: } \begin{aligned}
.98 \cdot\left(1+r_{20}\right) & >1 \\
\left(1+r_{\text {ann. }}\right) & >(1.0204)^{365 / 20}
\end{aligned}
$$

${ }^{11}$ If the customer develops liquidity problems, will she repay the TC already on her balance sheet for the most recent input shipment? While there are strong repayment pressures, she also considers the availability of other funds in her repay-or-delay decision. The supplier does not play an active role in the customer's "credit extension" decision. Suppose instead that a current credit customer wants to buy an input on credit in a time of tight money. Will the supplier extend her TC? Almost surely, yes: TC is tied to product sales, the supplier must keep steady customers at this critical time 
Table 1

Supplier Credit Policy to

Different Customer Types

\begin{tabular}{c||c|c|c|c|c|c||}
\hline \multicolumn{1}{|c||}{} & \multicolumn{6}{c||}{$\begin{array}{c}\text { Supplier, at time of Sale to: } \\
\text { type }\end{array}$} \\
\cline { 2 - 7 } & \multicolumn{2}{c||}{ Current credit } & \multicolumn{2}{c||}{ Current non-credit } & \multicolumn{2}{c||}{ New } \\
\hline $\begin{array}{c}\text { Supplier's credit } \\
\text { policy }\end{array}$ & $\begin{array}{c}\text { do not } \\
\text { offer TC }\end{array}$ & offer TC & $\begin{array}{c}\text { do not } \\
\text { offer TC }\end{array}$ & offer TC & do not offer TC \\
\hline $\begin{array}{c}\text { Customer } \\
\text { reaction }\end{array}$ & $\begin{array}{c}\text { no } \\
\text { purchase }\end{array}$ & purchase & purchase & purchase & $\begin{array}{c}\text { no } \\
\text { purchase }\end{array}$ & purchase \\
\hline $\begin{array}{c}\text { Effect on } \\
\text { AP/Sales }\end{array}$ & no change & no change & no change & rise & no change & fall \\
\hline
\end{tabular}

The table shows how a supplier's "offer TC" decision at the product sale impacts his customer and the effect on AP/Sales during "normal" times, i.e. non-tight money periods. We assume a customer prefers TC to cash so always purchases if TC is offered. We also assume to "not offer TC" to a current credit customer discourages her, unimportant if the supplier's terms remain constant (see Ng et al (1999)). Finally, we assume a relationship is built by non-credit sales; the supplier never offers a new customer TC without her first buying with cash. Other columns are self-explanatory. For example, in the third column the supplier does not offer TC to a current non-credit customer, who is not discouraged since she views it as policy. The supplier's average credit sales and thus AP/Sales remain the same.

Previous empirical evidence on the existence of the finance motive is mixed ${ }^{12}$. Brechling and Lipsey (1963) discover a component of TC unexplained by sales that is systematically influenced by monetary policy. Coates (1967), however, using a different sample of British manufacturing firms, does not concur. Petersen and Rajan (1995) examine TC in a cross-section study investigating bank-firm relations. They find, after controlling for age, incorporation status, profits, and bank relationships, that the value of firms' book assets positively and significantly influence the percentage of TC discounts taken. This supports that small firms are less able to exploit TC discounts due to fewer alternative credit sources. And it suggests that we try to link delayed repayment TC use to credit constrained firms in times of duress.

in the business cycle. If the supplier holds finished goods and faces slower sales, he faces liquidity problems anyway - the choice is an unpleasant one of holding inventories or AR.

${ }^{12}$ Our view of the finance motive is distinct from the redistribution hypothesis; Meltzer (1960), Jaffee (1971), Duca (1986). It posits that liquid (large) suppliers pass funds via TC to illiquid (small) customers. It implies, though, that large firms overwhelmingly supply small customers. We do not believe such a distribution is predominant. Further, TC flows both to and from the trade sectors (small firms buy goods from wholesalers). This TC flow distribution also dissuades us from putting structure on accounts receivable (TC given), so we consider it simply another asset. 


\section{II.C TC during Monetary Contractions:}

The finance motive predicts that firms ordinarily avoid the unattractive and expensive finance TC as loan substitute. If banks restrict credit, though, those firms depending on banks for funds are likely to be forced to use finance TC, while those with alternatives ignore it. We can re-examine Table 1 to summarize how the influences on TC change at the onset of tight monetary policy. The only change the supplier may make is to restrict new offers of TC to current non-credit customers (as above, we assume suppliers never offer TC to new customers). The corresponding change in Table 1 is to remove the fourth column's influence, and this induces AP/Sales to fall thus biasing against observing TC's finance motive.

We have noted the costliness of TC's finance motive, but since the supplier's terms of TC remain constant over time, it must surely become relatively cheaper than bank loans for firms to use it. It is the imperfect substitutability of TC and bank loans that allows us to observe systematic TC vs. loan usage differences across tight and easy money periods ${ }^{13}$. Figure 3 shows a customer switches to TC finance when the effective loan price (which includes the influence on price of quantity constraints) rises above the effective cost of TC (which includes all implicit costs), and this is more likely during tight money. AP/Sales, our indicator of TC's finance

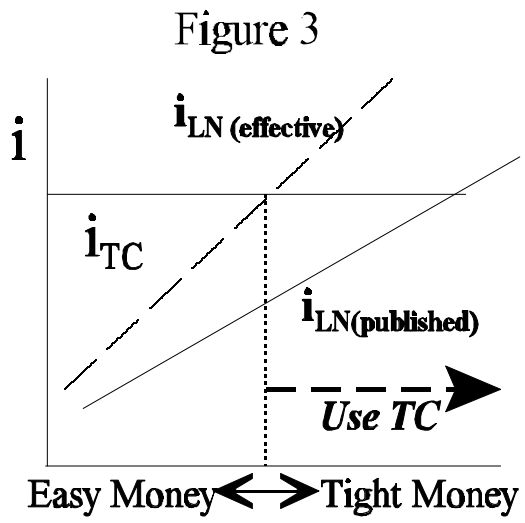
motive, indicates binding credit constraints, useful especially since published loan rates are well known to poorly represent a market-clearing price for loans ${ }^{14}$. So even though TC is usually very expensive, the unavailability and high cost of bank loans means TC is invoked during tight money periods.

A Fed policy contraction first raises short-term interest rates and slows the growth of reserves, thus inducing banks to scale back loan supply. Gertler and Gilchrist (1994) suggest that banks alter the loan distribution since small firms' loans decelerate while large firms' loans accelerate. The bank lending channel predicts that it is loan supply causing the decline in small firms' loans, not a demand reduction from lower activity. Using the logic of Kashyap, et al, we conclude that if small firms increase AP/Sales, a proxy for an unattractive loan substitute, it rules out demand and supports a supply phenomenon. Finance TC is a more

${ }^{13}$ Given that TC has constant terms and if firms viewed it as a perfect substitute to loans, then loan supply shifts would easily be indicated by loan quantity changes.

${ }^{14}$ Since banks constrain the quantity of loans as well as raise the asked return on loans, the actual price of loans to firms may be higher than the banks' advertised loan rates. 
appropriate instrument for this test than commercial paper since, as Oliner and Rudebusch (1996) note, the rise in commercial paper cannot inform about small firms which do not issue it.

This is then a clear test of the bank lending channel. After a contractionary policy shock, if we observe firms increasing AP (controlling for sales), they are affected by the finance motive, i.e. the bank lending channel exists. For if there were no bank lending channel, then some firms are inexplicably switching (at least according to the "money channel" view) into a unattractive substitute for bank loans.

\section{Evidence from the Quarterly Financial Reports (QFR)}

The data clearly show the transactions motive has a very strong effect on manufacturing firms' TC: sales declines are accompanied by nearly proportional TC declines. However, in tight money episodes, both small and large firms use these expensive funds to an extent not explained by the transactions motive. It seems to support the finance motive: firms are unable to access other credit to satisfy their needs. Concerning the bank lending channel, it indicates a strong demand for credit and suggests that credit supply, the province of banks, is responsible for the small firms' decline in loan growth observed by Gertler and Gilchrist. We will concentrate on the anomalous large firm behavior in part IV below.

\section{III.A. Description of the QFR Data}

We classify firms by size following Gertler and Gilchrist (1994), among others. It is based on the idea that young, relatively unknown firms and those having low collateral are also likely to be small ${ }^{15}$. These firms are often argued to be especially prone to information asymmetries; so they likelier require intermediaries to circumvent the high information requirements of open market debt. Some direct empirical support is provided by Calomiris and Hubbard (1991) who examine the imposition of a surtax on undistributed profits in 1935 and find that smaller asset size brings higher costs of external finance.

We use various indicators of the stance of monetary policy. One especially suitable for illustrative purposes is "Romer dates". Romer and Romer (1989) examine Federal Open Market Committee meeting notes to identify deliberate policy-initiated disinflations. "Romer" dates' exogeneity is not uncontroversial, but they conveniently indicate tight policy; and our results are robust to other policy indicators. In regression-

${ }^{15}$ An asset criterion assumes book assets are positively correlated with tangible assets, important since banks prefer firms with greater tangible assets (for a given level of sales) due to greater collateral. 
based analysis, we follow Laurent (1988) and many others to utilize measures based on the Fed funds rate. In the impulse response functions reported below, we use the term spread, the difference between 10 year bond rates and the Fed funds rate. Results were not materially influenced by using other monetary policy indicators such as monetary aggregates.

A problem with implementing this small-large distinction is that few data sources include small firms. We follow Gertler and Gilchrist (1994) and Oliner and Rudebusch (1996) to use QFR (Quarterly Financial Reports), published by the Census Bureau and based on Internal Revenue Service corporate tax returns. This set aggregates firm data according to 8 nominal asset sizes in the range of assets (in millions of dollars): below \$5, \$5-10, \$10-25, \$25-50, \$50-100, \$100-250, \$250-1000, and over \$1000. The QFR provides income statements and balance sheets for all large firms and a sample of small firms (only those with assets over $\$ 250,000$ are presently sampled).

As Gertler and Gilchrist (1994) note, the QFR categorization of firms in nominally valued asset sizes, unaltered since 1959, makes it difficult to apply time series methods (please see footnote 7). We follow their method ${ }^{16}$ (Appendix 1 gives details) and classify firms as small in a given period if they are members of the asset groups accounting for the lowest $30 \%$ of the total sales distribution. As so formed, the small firm category includes firms with the following asset groups (in millions of dollars): under $\$ 25$ until 1967, $\$ 50$ until 1971, \$100 until 1976, \$500 until 1989, and finally $\$ 1000$ until the present. The method described in appendix I avoids discontinuities when the groupings change. We are also confident the resulting firm classifications yield distinct types of firms. For example, the variance of large firms' cash and loans (in growth rates) are almost three times greater than small firms ${ }^{17}$.

We also make adjustments for definition changes in the QFR data (see again appendix I). We convert nominal data into real using the wholesale price index (except GDP: the implicit price deflator). The series are deseasonalized by subtracting the mean deviation of each respective season, calculated after detrending the series with a five quarter weighted moving average; Brockwell and Davis (1991).

${ }^{16}$ A preliminary version of Gertler and Gilchrist (1994) finds this method gives similar results as using absolute (nominal) size categories.

${ }^{17}$ Surprisingly, the data shows that large firms' loans and cash are very volatile and less synchronized with sales than small firms'. The detrended large firm loans and cash series' correlation with sales are .03 and .08 compared with small firms' .69 and .34, respectively. 


\section{III.B. First QFR Evidence:}

The transactions motive is strongly evident in the QFR data since firms' AP and sales are nearly proportional over the thirty years. Ideally, input purchases should be used to control for this strong transactions motive to isolate finance TC, but this variable is not included in the $\mathrm{QFR}^{18}$. Thus, when we then seek to measure TC independent of its transactions use, we focus on changes in the ratio AP/sales. The top graph in Figure 1 shows that TC is at times disproportional to sales, often corresponding to monetary policy contractions as indicated by the vertical lines on Romer dates. Also note that both types of firms act similarly and indeed it is difficult to discern differences between them in the most recent periods.

To focus on finance TC during tight monetary policy times, we compare the behavior of AP/sales at Romer dates to other times. We check the variance of the entire series of residuals from a detrending regression and of tight and easy money sub-periods ${ }^{19}$. The means of the AP/sales residuals are positive in tight money and negative at other times. Moreover, the variance of both series are more than twice as large during tight money (table 2), statistically significant at the $1 \%$ level. Figure 4 shows more detail in averaging increases in TC over the six Romer dates in the sample. We define an episode to consist of the detrended series of interest (in log differences) 4 quarters before and 12 quarters after the Romer date ${ }^{20}$. The AP/sales ratio increase shows that small firms are slow to repay their TC. Small firms seem here slightly more influenced by the finance motive than large firms.

For additional insight on whether firms are credit constrained, we consider cash, the most liquid asset (this includes their government securities holdings in QFR). For a given amount of sales, a low cash level indicates firms' inability to repay their suppliers. The bottom graph in Figure 4 shows that small and large firms behave distinctively following Romer dates. Both face a steep fall in cash prior to the Romer date, but small firms rebuild their balances quickly, while large firms' balances continue to fall for the next 6 quarters. It supports small firms' flexibility: although credit constrained, they quickly make necessary adjustments to

${ }^{18}$ We verify that AP/Sales behaves like AP/Production by adding inventory changes to sales to approximate production. We do this also for the Compustat data below (see Figure 7).

${ }^{19}$ Results were robust to tight money periods defined as 12 or 16 quarters after Romer dates.

${ }^{20}$ We compute a simple series growth average for each succeeding period of the episode and then cumulate to obtain levels. We ignore late fourth episode periods to avoid double counting (this Romer date is the 1979-1981 recession-recovery-recession). Finally we normalize to zero by subtracting the initial average period's level from each other average period's level. 
survive the bad times. Large firms, with a greater financial load due to inventories ${ }^{21}$ are much worse off for a longer period ${ }^{22}$.

We next compare small and large firms using forecast errors at times of tight money which permit inference of the impact of an unexpected monetary policy action ${ }^{23}$. Large firms' actual AP decline slightly relative to the level forecasted and then slowly recover. Small firms' AP declines immediately and substantially. This is consistent with the transactions motive's prediction that AP closely follows sales. Applied to the $\mathrm{AP} / \mathrm{sales}^{24}$ series to isolate TC from the transactions motive, forecast errors show that both large and small firms' series increase (Figure 5) by approximately .01 after eight quarters, a moderately large increase given this (detrended) variable's standard deviation of .007.

To sum up this first pass at evidence, TC declines as predicted by the transactions motive following the onset of tight money. We find, however, that firms generally increase the finance-related use of $\mathrm{TC}^{25}$. Interestingly, large firms increase TC/Sales earlier than small firms after monetary policy shocks.

\section{III.C. VAR Analyses:}

We next use unrestricted VARs following Sims (1980), and many others. Although this approach has limited power due to the many parameters estimated, it is nevertheless informative since it imposes a standard set of restrictions to achieve identification and its associated methodologies permit intuitive data analysis. Using VARs has become standard in empirical work. There remain, however, issues concerning arbitrariness in variable ordering and the relative imprecision of impulse response functions. We place the monetary policy indicator and GNP variables first since they are shown to be unaffected by the firm level

\footnotetext{
${ }^{21}$ Gertler and Gilchrist suggest the subdued rise in small firms' inventory/sales reflects a
} frustrated desire to smooth production. Alternatively, large firms' relatively rigid operations may make their inventory build-up unavoidable.

${ }^{22}$ It is also apparent in a comparison of impulse response functions below, see Figures 4 and 5.

${ }^{23}$ More specifically, first regress as of the date of the monetary shock the monthly change in e.g. detrended log AP on a constant, trend and eight own-lags (using four lags in the first episode due to insufficient data). We use forecasts of AP conditional on predicted values after the forecast date. We then cumulate the log changes to obtain log level AP forecasts that we subtract from the actual series. Finally, we compute a simple average over the different episodes.

${ }^{24}$ We tried also bivariate forecasts since AP/sales is likely influenced by other variables (e.g. inventories). We found that the fit improved, but results did not materially change.

${ }^{25}$ The TC reduction in the third Romer episode may be related to a structural break in 1973. 
variables in Granger Causality tests. We place the price level variable last, assuming price stickiness. The firm-level series are placed between these macro variables. It is important to note, though, that other orderings brought essentially identical results. For stationarity, all non-ratio, non-interest rate variables are put into log-differenced form. An improved characterization of the data is obtained by detrending with log, constant, and quadratic terms. Finally, the imprecision of the impulse response functions are made explicit by including one-standard deviation error bounds, calculated in an algorithm based on asymptotic theory by Lütkepohl (1993).

We first set up two systems, one for small firms and one for large ${ }^{26}$. The macro variables GDP, price level and the monetary policy indicator (specifically, the spread between the Fed funds and long-term Treasury bond rates) are included in each system. We tried monetary aggregates (e.g. M2), but believe they contain too much bank behavior to indicate central bank policy (M2 shocks tended to elicit slightly stronger reactions in the TC series than with interest rate based indicators).

The small firm system consists of the macro variables along with inventory/sales, cash/sales and $\mathrm{AP} /$ sales (equation 1). The idea is to trace the sequence of events within firms occurring after a monetary policy shock as indicated by a higher rate spread. We include the inventory to sales ratio to exploit information it gives on the higher funding load on large firms. We include the cash to sales ratio to exploit information on the firms' differing relative liquidity positions.

(1) $X_{t}=\sum_{i=1}^{4} \beta_{1} \Delta G D P_{t-i}+\sum_{i=1}^{4} \beta_{2}(R F F-R T B)_{t-i}+\sum_{i=1}^{4} \beta_{3} \Delta \frac{\text { Invy }}{\text { Sales }_{t-i}}+\sum_{i=1}^{4} \beta_{4} \Delta \frac{\text { Cash }}{\text { Sales }_{t-i}}+\sum_{i=1}^{4} \beta_{5} \Delta \frac{\text { AP }}{\text { Sales }_{t-i}}+\sum_{i=1}^{4} \beta_{6} \Delta P_{t-i}+\epsilon_{t}$

(Note that $\mathrm{X}_{\mathrm{t}}$ is a vector of the right hand side variables).

The macro variables have strong influence on small firms in variance decompositions and Granger causality tests. But the important relationships between small firm variables observed in the earlier descriptive evidence are now given statistical significance in the impulse response function (Figure 6). The $\mathrm{AP} / \mathrm{sales}$ ratio rises significantly soon after the shock, although the reaction quickly dissipates. In the first four quarters of the episode, we see that $\mathrm{AP} /$ sales rise prior to the sharp rise in inventory/sales. Cash/sales

${ }^{26}$ A nine-variable system (consisting of macro variables and each firms' sales, AP/cash, and loans, see Figure 8) verifies partial systems do not ignore important interactions. It replicates Gertler and Gilchrist (small firms' deeper fall in sales while large firms' (not small firms') loans rise), but it also shows large firms' stronger AP/cash rise consistent with small firms' flexibility bringing quick recovery while large firms' rigidity inducing longer illiquidity. 
drops lower throughout the first four quarters (again indicating that small firms find themselves at the end of their liquid reserves).

In the large firm system, a similar pattern arises in the impulse response function (Figure 7).

AP/sales increases sooner, but at a more gradual pace than the small firms. The large firms' inventory to sales ratio rises about twice as much as in the small firm system. Large firms deviate most from small firms in suffering a much lower cash to sales ratio, which continues significantly for 12 quarters after the shock. It suggests that small firms are more flexible in recovering from the constraints quickly.

To sum up the VAR impulse response function evidence, we find it consistent with the idea that firms have strong demand for credit, at least in the early stages tight money episodes. Small firms' increase in AP/sales is as predicted by the bank lending channel. The increase by large firms' AP/sales is surprising. We suspect it to be related, though, to their higher inventory to sales ratios. Further support is given by small firms' short drop in cash while large firms suffer with lower money balances for a full three years following the monetary shock. This seems to indicate that large firms also suffer from constraints, and indeed, for a longer time than do small firms. The purpose of the next section is to examine large firms' characteristics to determine whether this is indeed the case.

\section{Evidence from Compustat: TC and Large Firms}

The QFR provides surprising evidence that even large firms use greater amounts of TC relative to sales at times of tight money. Why should firms generally accepted as less prone to information problems and thus perceived as less risky by banks resort to less appropriate substitute credit? Do funding problems also reach those firms? Or do large firms use market power to "extend" TC credit from their suppliers at low perceived cost? To answer this issue we seek characteristics of large firms associated with the behavior and so we turn from QFR semi-aggregated to Compustat individual firm data. In data appendix II, we show that the sets provide complementary information, i.e. the large firms we analyze in Compustat do not differ materially from those large firms aggregated in the QFR.

We construct an unbalanced panel of manufacturing firms and include failing firms since we believe they provide important information about business cycle effects. The July 1993 version of Compustat provides annual data until 1992 for all firms listed on an organized exchange in the United States. We include in the study all manufacturing firms in any Compustat file with over \$250 million in assets (in 1983 dollars), having non-zero, non-missing data for the relevant variables. Firms involved in major merger or acquisition 
activity are discarded from analysis of either individual firms or industries ${ }^{27}$. We also discard observations associated with highly improbable values, for instance an observation associated with negative sales or liabilities greater than assets. Non-ratio variables examined in a time dimension are deflated by the CPI obtained from Citibase.

As discussed in III.B. above, using sales to proxy transactions is not perfectly satisfactory since AP are more directly associated with a firm's purchases. Using sales would be acceptable if the firm produces and sells a good using each input in the same period as purchased. For example, we may measure greater $\mathrm{AP} / \mathrm{sales}$ (than $\mathrm{AP} /$ purchases, the "true" measure) if firms continue to make purchases as product sales fall during a downturn. We use Compustat's 'cost of goods sold' and verify that AP/purchases and AP/sales provide similar information (Figure 9). Furthermore, Compustat's annual frequency means bias is less likely: most firms complete their operating cycle well within one year. We continue to use AP/sales to avoid sacrificing observations and to facilitate comparison with the QFR data.

\section{IV.A. Descriptive Evidence from Compustat}

In this section we investigate the firm characteristics that influence their finance TC use during tight money. First we insure that one industry is not responsible for large firms' observed AP/sales increase. Figure $10^{28}$, illustrating non-trivial industries during the severe recession of 1979-1982, reveals that firms in different industries display similar behavior: a clear positive reaction in 1979, a more muted one in 1980, and increasingly negative responses in 1981 and 1982 as the recession becomes entrenched. This is consistent with the view that credit constraints bind in the early recession phase; Eckstein and Sinai (1986). We discount the oil industry, number 29 on Figure 10, since oil industry behavior reflected other factors ${ }^{29}$.

\footnotetext{
${ }^{27}$ We include these firms in aggregate studies since the merger is likely to have occurred within the manufacturing sector. We would include merged firms in the separate industry analyses if the merger involved firms in the same industry, but this information is not available.

${ }^{28}$ We construct the graphs as follows: divide industry AP by industry sales. Detrend ratio for each industry over the sample period. The industry relative TC in tight money (i.e. 1979-1982) vs. other times is indicated by the distance in Figure 10 from the observation to the zero axis.

${ }^{29}$ Yergin (1991) reports the Iran-Iraq war led to great uncertainty in oil firms' supply. "The rush to build inventories by oil companies, reinforced by consumers, resulted in an additional 3 million barrels per day of 'demand' above actual consumption... In sum, the panic buying to build inventories more than doubled the actual shortage and further fueled the panic."
} 
We next take a graphical approach to investigate important firm characteristics that may be associated with TC use (see associated regression results in part IV.B.). As first suggested by Whited (1992), a bond rating proxies that a firm has access to plentiful and relatively inexpensive external finance. The bond rating is clearly an important determinant in large firms' use of TC, as seen in Figure 11 (the bottom left graph shows rated and non-rated firms' detrended AP/sales averaged over the three Romer dates). The firms without this bond rating used TC with greater intensity during periods of tight money ${ }^{30}$.

Does the amount of cash on hand, controlling for assets, influence the use of TC? If a firm views TC as unattractive credit, its TC/sales ratio should fall if it holds a large amount of cash for the firm possesses the liquidity to repay its suppliers ${ }^{31}$. We assign firms into groups according to whether their mean (over time) ${ }^{32}$ cash over assets is below the $30^{\text {th }}$ or above the $70^{\text {th }}$ percentile of firms ${ }^{33}$ in the sample. We then aggregate the extreme groups' AP and sales and detrend the AP/sales ratio. We interpret differences in the groups' AP/sales at times of monetary tightness as related to their cash/assets ratio. Surprisingly, we find cash-rich firms used TC to a greater extent than cash-poor firms (Figure 12, left side). This behavior is inconsistent with our thesis, but other explanations are possible. For example, it may be that cash-rich firms must hold compensating balances or that their transactions cost savings are especially high in using TC (cash-poor firms' property, plant and equipment were much greater than cash-rich firms' $)^{34}$. We will revisit this issue in part IV.B below. When we eliminate from the sample those (few) very large firms (with over $\$ 50$ billion in

${ }^{30}$ We tested results omitting oil firms: the results are robust.

${ }^{31}$ Since the "cash-poor" firms had greater property, plant and equipment than the "cash-rich" firms, we expect that cash-poor firms would use TC more also for the reason that the cost savings are greater than if they were to liquidate their fixed assets. We are thus still puzzled by finding that cash-rich firms (save fewer transactions costs using TC rather than liquidating) use more TC than the cash-poor firms.

${ }^{32}$ Opler, et al. (1999) calculate quartiles of Compustat firms' cash/assets at each point in time. This is sensible if one is examining how cash/assets change over time. We are interested in the longterm determinants of firms' cash/assets behavior and its influence on TC use over the business cycle. This is why we calculate the percentiles of firms' average cash/assets over time.

${ }^{33}$ Results were robust to other cut-offs, e.g. 20th and 80th percentiles.

${ }^{34}$ Cross-section regressions for each of 1977,1978 , and 1979 (the latter two having especially tight money conditions) revealed no significant relation between cash/assets and TC/sales. Eliminating firms with bond ratings makes AP/sales much more similar between the $30^{\text {th }}$ and $70^{\text {th }}$ percentile groups, implying again that access to bond markets influenced the higher AP/sales by cash-rich firms in the full-sample graphs. 
assets), cash-rich firms used even more TC/sales at tight money times (see the right diagrams on Figure 12). It supports that monopoly power does not importantly explain firms' use of TC/sales, since we associate extreme size with monopoly power.

The asymmetric-information literature suggests that fast-growing firms may be especially sensitive to credit conditions. If these firms stretch their resources to the limit in the course of achieving rapid growth, they may be more sensitive to monetary shocks. For example, when they are buffeted by a demand shock, they do not have as large a safety margin as other firms and thus may use TC to a greater extent. We follow a similar procedure to that described in the above paragraph, but find little evidence to support this hypothesis, see the lower-right graph on Figure 11. It shows that both slow and fast growth large firms have similar behavior concerning TC/sales.

\section{IV.B. Simple Time Series Models}

We turn to time series regressions to exploit the common-sense idea that unexpected demand innovations can induce unanticipated build-ups in firms' inventories. When the shock occurs, the firm's production process continues while the fall in demand reduces sales. The resulting loss of liquidity and cost of holding finished goods inventories induces a demand for credit. In the model, each firm has a target level of inventories; it is costly to turn away customers due to stock-outs, yet it is also costly to hold inventories. This target is assumed to be a constant over time for simplicity. Since it is also costly to alter production, whether for increases (due to e.g. overtime) or for decreases (due to e.g. severance payments), firms do not adjust immediately to the new equilibrium. Using a partial adjustment equation (see e.g. Harvey, 1981)

$$
\text { (3) } F G I_{t}-t_{t-1}=\gamma\left(\overline{F G I}-F G I_{t-1}\right)+\epsilon_{t}
$$

Where FGI represents firms' finished goods inventories. Deviations from expected sales comprise the white noise innovations:

$$
\text { (4) } \epsilon_{t}=E_{t-1} \text { Sales }_{t}-\text { Sales }_{t}
$$

Firms finance inventory shocks with STC, short-term credit (e.g. bank loans), partly rolled over:

$$
\text { (5) } S_{T} C_{t}=\alpha S T C_{t-1}+\beta \hat{\epsilon}_{t}+\eta_{t}
$$

Or TC which has a transactions component:

$$
\text { (6) } T C_{t}=\delta P c h_{t}+\gamma \hat{\epsilon}_{t}+v_{t}
$$

(where "Pch" represents firms' purchases). To implement this model, we log and detrend aggregate series of 121 rated and 117 non-rated firms for each year 1973-1992. The inventory shocks are modeled as residuals 
from an AR-1 process derived from equation (3). We utilize firms' total inventories ${ }^{35}$ since this series has by far fewer missing observations in the Compustat data than the more theoretically appealing series finished goods inventories. We regress equations (5) and (6) separately on the rated and non-rated firms by ordinary least squares in the first column on the right and left side of Table $3^{36}$. First, we find that rated firms' credit has a long-lasting component that non-rated firms' do not $\left(\alpha_{\mathrm{R}}>\alpha_{\mathrm{NR}}\right)$. This may indicate that rated firms' banks are less likely to interrupt their credit than that of non-rated firms, consistent with a flight to quality (Bernanke, Gertler, and Gilchrist). Looking at the $\delta$ coefficients, we see reaffirmation of the strong transactions motive of TC. The AP and sales relation is stronger (although measured less accurately) in the rated firms $\left(\delta_{\mathrm{R}}>\delta_{\mathrm{NR}}\right)$. It may reflect that rated firms are more likely to obtain purchases on credit from their suppliers. The difference between the rated and non-rated firms is, however, not statistically significant. More interesting is the reaction to a temporary shock to inventories. Rated firms' loans rise by a greater extent than non-rated firms do $\left(\beta_{R}>\beta_{N R}\right)$, while non-rated firms increase TC more, $\left(\gamma_{N R}>\gamma_{R}\right)$. The difference in TC use by rated and non-rated firms is statistically significant at the $5 \%$ level. This is consistent with the logic of part II.B, non-rated firms, similar to the prototypical small firm, lack alternative funds sources and are therefore forced to fund unexpected shocks via TC.

As both rated and non-rated firms are affected by similar macroeconomic influences, indicated by the correlated regression residuals, we report results using the seemingly unrelated regression technique (SUR) in the next columns of Table 3. We find that this technique does indeed reduce the standard errors of the estimates in most cases. For example, it brings the t-statistics on the non-rated firms' long-lasting loan component to significance $\left(\alpha_{\mathrm{NR}}>0\right)$. A further specification (again using the SUR technique) was based roughly on the AP/sales variable used on the QFR data. The third columns of Table 3 show the results of regressing the inventory shocks on $\mathrm{AP} / \mathrm{Sales}$ and short-term loans. The coefficient estimates are roughly similar to the earlier two columns.

We utilize a specification incorporating the finance motive of TC to readdress the puzzling graphical evidence that cash-rich firms use more TC than cash-poor firms. The regression results in Table 4 reaffirm that cash-rich firms fund inventory shocks with TC, while cash-poor firms do not. Typically, cash-rich firms

\footnotetext{
${ }^{35}$ We obtain, though, similar results using firms' finished goods inventories.

${ }^{36}$ Our constructed purchase variable, defined as the cost of goods sold + the change in inventories, is obviously unsuited for this regression. We thus proxy purchases with sales.
} 
do not have a bond rating ${ }^{37}$, so they may be holding cash for precautionary purposes, since ready finance (indicated by the bond rating) is unavailable. This is supported by Opler, et al (1999), who study corporate cash holdings and give characteristics of cash-rich firms that can help explain the observed pattern of coefficients. Specifically, Opler et al find cash rich firms have lower cash-flows, are "substantially smaller", and are in industries with highly volatile cash flows. These characteristics are those we expect may make firms more likely to use TC for financing purposes. However, the significant positive coefficient of cash-rich firms that have a bond rating remains puzzling: we would think that these firms would use their alternative funds sources rather than TC.

The collateral banks require from firms for loans is often based on the amount of fixed assets on the firms' books. Those firms with low levels of collateral are usually less able to get loans. We split the firms in the Compustat data sample using a similar procedure to the above: we categorize firms as fixed asset rich if they are above the $70^{\text {th }}$ percentile of firms as measured by the book value of their property, plant and equipment relative to total assets. Table 5 shows that those firms with the greatest book assets do indeed use less TC than the other firms. Further, in each category of relative book asset size, those firms without a bond rating use more TC than those with a bond rating (differences in the coefficients are not significant in this case $)^{38}$. This evidence is again consistent with the idea that firms having liquidity problems and no access to alternative funds turn more to TC finance than other firms.

\section{Conclusion}

The bank lending channel posits that at the time of contractionary monetary policy shocks, loan reductions bring bank-dependent firms to reduce spending independently of changes in the cost of capital. We show that small firms, unlikely to have alternative finance sources, increase their use of an unattractive alternative to bank loans. It identifies the reduction in their loans as from supply, thus supporting the bank lending channel theory. Surprisingly, large firms also increase their finance trade credit, an apparent

${ }^{37}$ The correlation of firms that are cash-rich (above the $70^{\text {th }}$ percentile of cash holdings) and having a bond rating in each year is approximately -.20. The correlation of cash-poor firms and the bond rating is approximately .05 in each year.

${ }^{38}$ An exception is the book asset-rich firms. It is interesting to note the similarity between book asset rich rated firms and cash-rich rated firms: the coefficients are larger than expected. Does this indicate a class of firms which are given primacy in all forms of credit? 
contradiction to the bank lending channel since these firms are generally assumed to have access to cheaper credit, e.g. commercial paper. However, we find using the Compustat data that firms without bond ratings, firms that are cash-rich (indicating they are located in industries with e.g. volatile cash-flows), and firms that do not have large amounts of collateralizable assets use trade credit similarly to the small firms in the small/large firm semi-aggregated data. The large firms with a bond rating, i.e. those firms having alternatives, for the most part do not use trade credit finance. The bond rating is a mark of quality which gives them also primacy with loans from banks. This explains the puzzle in the earlier semi-aggregated large/small firm data: those large firms responsible for the increase in trade credit do not have alternatives. The firms with a bond rating are the firms which do not use trade credit at times of contractionary monetary policy. It reinforces that firms are using TC for financial reasons at these times. Firms without attractive alternatives are turning to costly last resort credit because banks have cut off their loans, again what the bank lending channel leads us to expect.

Gertler and Gilchrist (1994) show that "small firms account for a significant share of the decline in manufacturing that follows a shift to tight money". Many others have attempted to quantify the effect of constraints by using small firms. This paper shows that in order to gauge the full effect of credit constraints, we should not only measure the impact on small manufacturing firms, but also those large manufacturing firms that do not have a bond rating. Furthermore, to the extent that large manufacturing firms are preferred customers of the banks, since these large firms are also turning to unattractive TC, it implies that they are constrained in their use of bank loans. Thus, credit constraints are more widespread than previously believed. 
Table 2

Decomposition of Variance Between Easy and Tight Money Periods

\begin{tabular}{|c|c|c|c|c|c|c|}
\hline & \multicolumn{3}{|c|}{ Small AP/Sales } & \multicolumn{3}{|c|}{ Large AP/Sales } \\
\hline & Mean & Var. & Ratio & Mean & Var. & Ratio \\
\hline Entire Sample & & $\begin{array}{r}.00005 \\
.000007) \\
\end{array}$ & & & $\begin{array}{r}.00007 \\
(.000009) \\
\end{array}$ & \\
\hline $\begin{array}{c}\text { Tight Money } \\
\text { (65 periods) }\end{array}$ & .0004 & $\begin{array}{l}.00008 \\
(.00001)\end{array}$ & $337 *$ & .0012 & $\begin{array}{l}\mathbf{. 0 0 0 0 9} \\
(.00001)\end{array}$ & $108 *$ \\
\hline $\begin{array}{l}\text { Other times } \\
\text { (66 periods) }\end{array}$ & -.0004 & $\begin{array}{l}. \mathbf{0 0 0 0 2} \\
(.000005)\end{array}$ & & -.0011 & $\begin{array}{l}\mathbf{. 0 0 0 0 4} \\
(.000007)\end{array}$ & \\
\hline $\begin{array}{l}\text { Tight Money } \\
\text { (77 periods) }\end{array}$ & .0003 & $\begin{array}{l}\mathbf{. 0 0 0 0 7} \\
(.00001)\end{array}$ & 20 & .0008 & $\begin{array}{l}\mathbf{. 0 0 0 0 8} \\
(.00001)\end{array}$ & \\
\hline $\begin{array}{l}\text { Other times } \\
\text { (54 periods) }\end{array}$ & -.0003 & $\begin{array}{c}.00002 \\
(.000005)\end{array}$ & & -.0003 & $\begin{array}{l}\mathbf{. 0 0 0 0 4} \\
(.000007)\end{array}$ & \\
\hline
\end{tabular}

Standard errors within parentheses. *: ratios significant at $1 \%$. We regress ratios on constant, $\log$, linear, and quadratic trends. We calculate variance of residuals for 12 or 16 periods following Romer dates and compare them to variance of remaining periods. The test assumes independence of the samples.

Table 3

Time Series AP \& Pchs by Bond-Rating

\begin{tabular}{|c|c|c|c|c|c|c|c|c|}
\hline & \multicolumn{4}{|c|}{$T C_{t}=\delta P c h_{t}+\gamma \hat{\epsilon}_{t}+v_{t} \quad$ see text } & \multicolumn{4}{|c|}{$S T C_{t}=\alpha S T C_{t-1}+\beta \hat{\epsilon}_{t}+\eta_{t}$ see text } \\
\hline & & OLS & SUR & SUR & & OLS & SUR & SUR \\
\hline \multirow{3}{*}{ Rated } & $\delta_{\mathrm{R}}$ & $\begin{array}{l}1.31 * \\
(7.08)\end{array}$ & $\begin{array}{l}1.29 * \\
(7.52)\end{array}$ & & $\alpha_{\mathrm{R}}$ & $\begin{array}{l}.45^{*} \\
(3.32)\end{array}$ & $\begin{array}{l}.46^{*} \\
(4.14)\end{array}$ & \\
\hline & $\gamma_{R}$ & $\begin{array}{c}.03 \\
(0.18)\end{array}$ & $\begin{array}{c}-.01 \\
(-0.07)\end{array}$ & $\begin{array}{c}.01 \\
(1.32)\end{array}$ & $\beta_{\mathrm{R}}$ & $\begin{array}{l}1.74 * \\
(6.23)\end{array}$ & $\begin{array}{l}1.76^{*} \\
(7.41)\end{array}$ & $\begin{array}{l}1.88 * \\
(5.78)\end{array}$ \\
\hline & $\begin{array}{l}\bar{R}^{2} \\
\text { DW }\end{array}$ & $\begin{array}{c}.83 \\
1.42\end{array}$ & $\begin{array}{c}.83 \\
1.37\end{array}$ & $\begin{array}{c}.10 \\
1.28\end{array}$ & $\begin{array}{l}\bar{R}^{2} \\
\text { DW }\end{array}$ & $\begin{array}{c}.75 \\
2.62\end{array}$ & $\begin{array}{c}.76 \\
2.63\end{array}$ & $\begin{array}{c}.61 \\
1.98\end{array}$ \\
\hline \multirow{3}{*}{$\begin{array}{l}\text { Non- } \\
\text { Rated }\end{array}$} & $\delta_{\mathrm{NR}}$ & $\begin{array}{l}1.13 * \\
(13.78)\end{array}$ & $\begin{array}{c}1.15^{*} \\
(15.07)\end{array}$ & & $\alpha_{\mathrm{NR}}$ & $\begin{array}{l}.16 \\
(.97)\end{array}$ & $\begin{array}{l}.34 * * \\
(2.41)\end{array}$ & \\
\hline & $\gamma_{\mathrm{NR}}$ & $\begin{array}{l}.47 * * \\
(2.42)\end{array}$ & $\begin{array}{l}.39 * * \\
(2.21)\end{array}$ & $\begin{array}{c}.04 * \\
(3.07)\end{array}$ & $\beta_{\mathrm{NR}}$ & $\begin{array}{c}1.27 * * \\
(2.64)\end{array}$ & $\begin{array}{l}1.39 * \\
(3.39)\end{array}$ & $\begin{array}{c}1.33 * \\
(2.98)\end{array}$ \\
\hline & $\begin{array}{l}\bar{R}^{2} \\
\text { DW }\end{array}$ & $\begin{array}{c}.93 \\
1.67\end{array}$ & $\begin{array}{c}.93 \\
1.55\end{array}$ & $\begin{array}{c}.38 \\
1.49\end{array}$ & $\begin{array}{l}\bar{R}^{2} \\
\text { DW }\end{array}$ & $\begin{array}{c}.24 \\
2.39\end{array}$ & $\begin{array}{c}.24 \\
2.58\end{array}$ & $\begin{array}{c}.29 \\
2.06\end{array}$ \\
\hline
\end{tabular}

$\mathrm{t}$-statistics are given in parentheses below the corresponding parameter estimates. *** represent $.01, .05$ levels of significance respectively. 
Table 4

Time-Series $\quad(\text { TC/Sales })_{t}=\lambda \hat{\epsilon}_{t}+v_{t}$

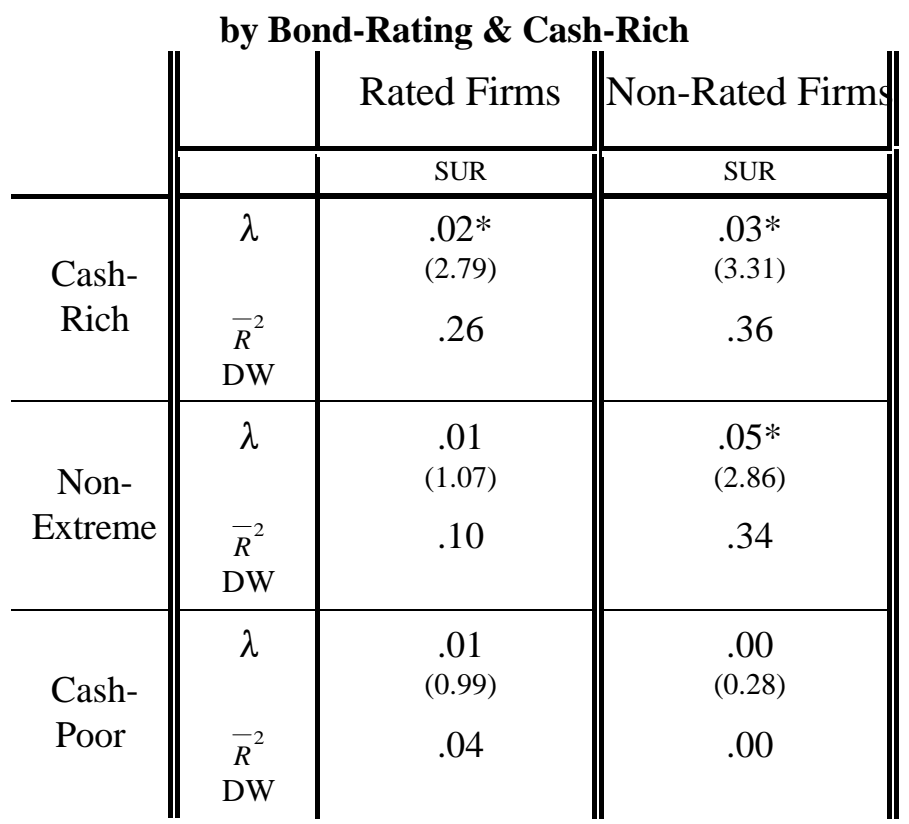

t-statistics are given in parentheses below the corresponding parameter estimates. $* * *$ represent $.01, .05$ levels of significance respectively.

Table 5

Time-Series $\quad(\text { TC/Sales })_{t}=\lambda \hat{\epsilon}_{t}+v_{t}$

\begin{tabular}{|c|c|c|c|}
\hline & \multicolumn{3}{|c|}{ y Bond-Rating \& Book-Asset-Rich } \\
\hline & & Rated Firms & Non-Rated Firms \\
\hline & & SUR & SUR \\
\hline Book & $\lambda$ & $\begin{array}{c}.02 \\
(1.64)\end{array}$ & $\begin{array}{c}.01 \\
(0.60)\end{array}$ \\
\hline $\begin{array}{l}\text { Asset- } \\
\text { Rich }\end{array}$ & $\begin{array}{l}\bar{R}^{2} \\
\text { DW }\end{array}$ & .13 & .03 \\
\hline Non- & $\lambda$ & $\begin{array}{c}.03^{*} \\
(4.31)\end{array}$ & $\begin{array}{l}.04 * * \\
(2.36)\end{array}$ \\
\hline Extreme & $\begin{array}{c}\bar{R}^{2} \\
\text { DW }\end{array}$ & .46 & .21 \\
\hline Book & $\lambda$ & $\begin{array}{l}.02 * \\
(3.05)\end{array}$ & $\begin{array}{c}.03 * \\
(4.74)\end{array}$ \\
\hline $\begin{array}{l}\text { Asset- } \\
\text { Poor }\end{array}$ & $\begin{array}{c}\bar{R}^{2} \\
\text { DW }\end{array}$ & .28 & .52 \\
\hline
\end{tabular}

t-statistics are given in parentheses below the corresponding parameter estimates. ${ }^{*}, * *$ represent $.01, .05$ significance levels respectively. 


\section{References:}

Bernanke, Ben (1993) "Credit in the Macroeconomy", Quarterly Review, Federal Reserve Bank of New York Quarterly Review

Bernanke, Ben (1993) Discussion in Carnegie-Rochester Conference Series on Public Policy 39

Bernanke, Ben and Alan Blinder (1988) "Credit, Money, and Aggregate Demand" American Economic Review

Bernanke, Ben and Alan Blinder (1992) "The Fed Funds Rate and the Channels of Monetary Policy" American Economic Review

Bernanke, Ben and Mark Gertler (1995) "Inside the Black Box: The Credit Channel of Monetary Policy Transmission" Journal of Economic Perspectives

Brechling, F.P.R. and R.G. Lipsey (1963) " Trade Credit and Monetary Policy" Economic Journal

Brockwell, Peter and Richard Davis (1991) Time Series: Theory and Methods Springer Verlag

Calomiris, Charles and R.Glenn Hubbard (1991) "Tax Policy, Internal Finance, and Investment: Evidence from the Undistributed Profits Tax, 1936-1937; mimeo

Coates, J.B. (1967) "Trade Credit and Monetary Policy: A Study of the Accounts of 50 Companies" Oxford Economic Papers

Cole, Rebel A. and John D. Wolken (1995) "Financial Services Used by Small Businesses: Evidence from the 1993 National Survey of Small Business Finances" Federal Reserve Bulletin, July pp. 629-667

Daripa, Arupratan (1997) "Lenders Who Must Borrow: Underinvestment in Aggregate Equilibrium and The Role of Trade Credit”, mimeo, Birkbeck College, University of London

Davey, Patrick (1989) "Corporate Leveraging and Financing Plans: 1989-1992" The Conference Board $\underline{\text { Research Bulletin } 235}$

Duca, John (1986) "Credit Rationing and Trade Credit as an Alternative Source of Short Term Credit" unpublished Ph.D. dissertation; Princeton University

Eckstein and Sinai (1986) "Mechanisms of Business Cycle in Postwar Era" in Gordon, ed. The American Business Cycle: Continuity and Change

Engle and Granger (1986) "Cointegration and Error Correction" Econometrica

Ferris, J. S. (1981) "A Transactions Theory of Trade Credit Use" Quarterly Journal of Economics

Gertler, Mark and Simon Gilchrist (1993) "The Role of Credit Market Imperfections in the Monetary

Transmission Mechanism: Arguments and Evidence" Scandinavian Journal of Economics 43-64

Gertler, Mark and Simon Gilchrist (1994) "Monetary Policy, Business Cycles, and the Behavior of Small Manufacturing Firms" Quarterly Journal of Economics 
Greene, William H. (1993) Econometric Analysis, $2^{\text {nd }}$ Edition, Macmillan Publishing Company

Harvey, Andrew (1981) The Econometric Analysis of Time Series, Camelot Press Ltd.

Jaffee, Dwight (1971) Credit Rationing and the Commercial Loan Market, John Wiley and Sons

Kashyap, Anil, Jeremy Stein, and David Wilcox (1993) "Monetary Policy and Credit Constraints: Evidence from the Composition of External Finance" American Economic Review

Kashyap, Anil, Jeremy Stein, and David Wilcox (1996) "Monetary Policy and Credit Constraints: Evidence from the Composition of External Finance: Reply" American Economic Review

Kashyap, Anil and Jeremy Stein (1994) "Monetary Policy and Bank Lending" in Mankiw, ed. Monetary Policy

Kashyap, Anil, Owen Lamont and Jeremy Stein (1992) "Credit Conditions and the Cyclical Behavior of Inventories: A Case Study of the 1981-1982 Recession" mimeo, University of Chicago

Kindleberger (1993) A Financial History of Western Europe

Laurent, Robert D. (1988) “An Interest Rate Based Indicator of Monetary Policy” Economic Perspectives, Federal Reserve Bank of Chicago

Lütkepohl, Helmut (1993) An Introduction to Multiple Time Series, Springer Verlag

Meltzer, Alan (1960) "Mercantile Credit, Monetary Policy, and the Size of Firms" Review of Economics and $\underline{\text { Statistics }}$

Mian, Shehzad L. and Clifford W. Smith, Jr. (1992) “Accounts Receivable Management Policy: Theory and Evidence" Journal of Finance

Mishkin, Frederic (1998) The Economics of Money, Banking and Financial Markets, fifth ed., Addison Wesley

Moody's Industrial Manual, 1987

Nadiri, M.I. (1969) "Determinants of Trade Credit in US Total Manufacturing Sector" Econometrica

Ng, Chee K., Janet Kiholm Smith, and Richard L. Smith (1999) "Evidence on the Determinants of Credit Terms Used in Interfirm Trade" Journal of Finance

Nilsen, Jeffrey (1994) The Impact of Credit Markets on Monetary Policy unpublished Ph.D dissertation; Princeton University

Oliner, Stephen and Glenn Rudebusch (1996) "Monetary Policy and Credit Constraints: Evidence from the Composition of External Finance: Comment" American Economic Review

Opler, Tim, Lee Pinkowitz, Rene Stulz and Rohan Williamson (1999) "The determinants and implications of corporate cash holdings" Journal of Financial Economics

Petersen, Mitchell and Raghuram Rajan (1994) "The Benefits of Lending Relationships: Evidence from Small Business Data" Journal of Finance 
Petersen, Mitchell and Raghuran Rajan (1995) "The Effect of Credit Market Competition on Firm-Creditor Relationships" Quarterly Journal of Economics

Quarterly Financial Report for Manufacturers (1959-1991) U.S. Census Bureau

Ramey, Valerie (1992) "Source of Fluctuations in Money: Evidence from Trade Credit" Journal of Monetary Economics 171-193

Romer, David and Christina Romer (1989) "New Evidence on Monetary Transmission Mechanism" Brookings Papers on Economic Activity

Schwartz, Robert (1974) "An Economic Model of Trade Credit" Journal of Financial and Quantitative Analysis

Sims, Christopher (1980) "Macroeconomics and Reality" Econometrica

Ward's Business Directory (1988) US Private Companies - The Largest Private Plus Selected Public $\underline{\text { Companies }}$

Whited, Toni (1992) "Debt, Liquidity Constraints, and Corporate Investment: Evidence from Panel Data" Journal of Finance

Yergin, Daniel (1991) The Prize: The Epic Quest for Oil, Money and Power Simon and Schuster 


\section{Appendix I: QFR and Definition of Large and Small Firms}

Gertler and Gilchrist (1994) define small manufacturing firms as consisting of the lowest 30th percentile of the total manufacturing sales distribution. We follow this method, which takes the eight size classes provided by the QFR and estimates growth rates for a cumulation called large firms and one called small firms. More specifically, the cell that contains the $30^{\text {th }}$ percentile of nominal sales is considered the 'marginal size class' for that period. This will be the cut-off point that determines for the other variables the size of small and large firms. That is, a weight to be applied to the other variables is then calculated. Very simply, the growth rate of small firms will be a weighted average of the classes up to the marginal size class and that up to and including the marginal size class. At this point the other variables are cumulated up from the smallest class to the largest. The growth rate of these partially accumulated cells are then calculated using the sales-based weights.

1. Determine the marginal size class with respect to sales. We cumulate each successively larger class until $30 \%$ of total sales is attained. This group includes the marginal size class and defines the upper bound of small firms.

2. This simultaneously determines the lower bound group: all classes of small firms up to but not including the marginal size class.

3. We now determine sales-based weights to apply to the other series we study, e.g. AP. The weights formula is given by Gertler and Gilchrist: if the firms with sales below the 3rd class account for $\mathrm{x}$, such that $\mathrm{x}<30 \%$ and the 4 th class accounts for $\mathrm{y}$, such that $\mathrm{y}>30 \%$. Then the weight to apply is: $\mathrm{w}=(\mathrm{y}-$ $30) /(y-x)$. And the growth rate for the small firm series is $w * g+(1-w) * s$, where $g$ is the growth rate associated with the group having $\mathrm{x}$ and $\mathrm{s}$ is the growth rate of the group having $\mathrm{y}$. (The idea is that we apply the sales-determined weights to find the growth of the marginal size class to allocate to the lower and upper bound groups).

4. Get the initial value for small and large firms.

5. Cumulate up to achieve levels series.

6. Log transform, and detrend by using residuals from a regression of each series on a constant, linear, quadratic and log terms.

\section{Appendix II: Compustat Data}

In a given period, the amount of purchases a firm makes is proportional to the credit it receives from its suppliers for those purchases. The variable cost of goods sold is easily transformed using changes in inventories into cost of purchases:

(D1) $\operatorname{Invy}_{t-1}+C G P_{t}-\operatorname{Invy}_{t}=C G S_{t}$ $C G P_{t}=C G S_{t}+\Delta$ Invy $_{t}$ 


\section{Comparison: QFR vs. Compustat:}

A danger in using another data set is that 'guilty' firms may be missing in the second data set. For example, if large private firms were responsible for the increase in AP/sales in QFR, we could not hope to find it in Compustat since private firms are not in that sample. This is a mute point since AP/sales also increases in Compustat. Bias could also arise if firms responsible for a small part of the increase in QFR are overrepresented in Compustat. Since Compustat over-represents large firms, this appendix will aim to show why it is that we are confident that any bias is minor.

We use a sample of firms with over \$250 Million in total nominal assets. This cut-off is chosen to capture the essence of large firms yet keep a simple scheme for comparing firms in the data sets. Replicating the small and large firm definitions in Gerter and Gilchrist (1994) would be an empty exercise since it is, after all, an approximation required by QFR. Many smaller firms in QFR do not exist in Compustat since all Compustat firms are publicly traded.

\section{Coverage of the QFR and Compustat}

In this section we compare important series (total assets, sales, inventories, short-term credit, and trade credit) between the data sets. Each data set has evolved to fit better its customers' needs. Thus even though QFR and Compustat cover nearly the same large firms, differences arising from e.g. accounting methods, timing, or sample coverage may bias one data set's view of a firm's behavior.

The QFR was created by the Federal Trade Commission and was later taken over by the Census Department. Its audience is primarily domestic agencies: for example, the Federal Reserve Board utilizes it to assess industrial debt structure and profitability. The Commerce Department uses it to determine corporate profits for national income accounting. The users likely influenced the Census Department in 1973 to require sample firms to account for foreign subsidiaries under equity investment instead of consolidating them, as was done previously. We discuss this change below. Compustat, on the other hand, seeks to attract investors and so views firms in terms of finances and ownership. It thus does not concern itself with the firm's specific role in one economy or another. Under generally accepted accounting principles followed by Compustat, a firm owning a majority stake in a distinct non-financial business unit must consolidate its accounts.

Figure A.1 shows raw series in the QFR and aggregated series in Compustat for firms over $\$ 250$ million dollars in nominal assets. One immediately apparent and disquieting point is the obvious difference in magnitude of the aggregated series. The Compustat series are 10-50\% larger than the corresponding QFR series. Further, the Compustat series also display greater variance around their trends (see especially total AP and total inventory, graphs 3 and 5).

\section{Accounting for the Difference in Series' Levels}

A QFR rule requires U.S. corporations to consolidate only domestic operations and thus exclude from their balance sheets the contribution of their foreign subsidiaries. At the date the rule was instituted (in 1973), most series exhibited an immediate drop of 10-20\%. To facilitate comparison over time, the Census Bureau provides 2 sets of numbers for each series in the 4th quarter of 1973. An adjustment factor for each series (the post- divided by the pre- adjustment numbers) can then be applied in all periods prior to the new rule to 
eliminate the discontinuity that would otherwise result. The early part of the series then approximates the series' behavior as if the QFR were domestic-only at the beginning of the sample period. Instead, this factor may be inverted and applied to subsequent periods to approximate the series' behavior as if the QFR had consolidated the international subsidiaries' accounts. This is only a rough approximation to an international QFR since there has been an increased degree of international integration since 1973. Further, the foreign subsidiaries' cyclical nature (not in the QFR) may differ from the domestic subsidiaries.

Surprisingly, few firms have a U.S. presence only to sell equity. Those likely to be in the U.S. for financial reasons, those paying the lowest U.S. taxes as a share of total taxes, also had a significant physical presence. We are unable to adjust their accounts to ignore assets unrelated to the real US economy since the firms do not provide this information to the S.E.C. It may be an important source of error in Compustat due to foreign multinationals' increased investment in the U.S. during the 1980's. Only the domestic part of the firms, however, are included in the QFR since they pay U.S. taxes. To gauge the importance of these firms, we adjust Compustat firms with a small manufacturing presence in the U.S. Specifically, we multiply each series by a tax factor, the amount of U.S. and foreign tax paid: $1-.4 *$ (foreign tax)/(federal tax + foreign tax). The graphs in Figure A.2 (ignore top right graph for the moment) show the series resulting from an "international" QFR (as described in the preceding paragraph) and "national" Compustat.

Another major difference is that the QFR includes all large firms while Compustat excludes privatelyowned firms. Although private firms can be large (e.g. the largest private manufacturer, BCI Holdings' 1988 sales of $\$ 11.3 \mathrm{bn}$ ), they are on average smaller. The fourth largest private firm, Mars, Inc. (\$6 billion 1988 sales) would be only the 31 st largest publicly-owned firm. Adding private firms having over $\$ 250$ million assets in 1983 dollars to Compustat would have increased total manufacturing sales by only $\$ 148$ billion $^{39}$ (Ward's 1988). The top right graph of Figure A.2 shows the effect of adding private firms' sales in 1988 to Compustat's sales. Omitting private firms may importantly affect results, however, if the private firms' cyclical behavior differs markedly from publicly owned firms'.

Several differences between the data sets fade in importance upon closer examination. For one, QFR accounts, like Compustat, conform to generally accepted accounting procedures and not tax methods, as might be expected from a data set constructed from tax returns. Regarding mergers and acquisitions, Compustat indicates the parties involved and leaves dealing with them to the user. The QFR excludes accounting of all subsidiaries that are financial in nature. This was true for Compustat as well until 1987 when the Financial Accounting Standards Board (FASB) required such firms to account for financial subsidiaries exactly like other subsidiaries. This ruling means that when a manufacturer purchases a bank, it must consolidate the bank's accounts with its own ${ }^{40}$. Compustat assists its users by providing one set of accounts applying the new standard and one ignoring it.

${ }^{39}$ These are self-reported sales in Ward's (1988).

${ }^{40}$ Compustat's treatment of the new FASB rule was sometimes inconsistent: it increased an oil firm's AP by the deposits of a purchased savings and loan!! 


\section{Differences in Cyclical Characteristics}

Since this paper investigates large firms' cyclical behavior, the match of the aggregate detrended series is of more importance than the raw series discussed above. To avoid timing problems, we include only firms with fiscal years ending in the fourth quarter. After aggregating by year, we transform each series into logs and then regress them on time and time-squared trends. The resulting residuals are the series as shown in Figure A.3. It is encouraging that the data sets nearly agree on the timing of the cyclical peaks and troughs.

The Compustat series, though, obviously display greater cyclicality. The source of this volatility is not due to combinations, since dropping firms involved in mergers and acquisitions brought even greater cyclicality. Nor does the volatility arise from applying a strict nominal cutoff of $\$ 250$ million in assets. This could occur if many firms hover near \$250 million in assets. During good times they rise above \$250 million and are thus included in this sample. When bad times come, however, their assets fall and may drop below $\$ 250$ million, so they would be dropped from the sample. We reconstructed the graphs of Figure A.3 using alternate selection criteria, e.g. include any firm which hit \$250 million at any time during the study, or include firms with assets averaging over $\$ 250$ million. Figure A.3 did not change to a perceptible degree. Neither is Compustat's greater international coverage the cause. Since nations' business cycles are not perfectly correlated, we expect that a data set including international entities would display less cyclicality.

The good news is that the volatility difference between the Compustat and QFR series washes out in ratio form. The graphs of Figure A.4 display three ratios in Compustat and the QFR with detrended versions immediately beneath them. The bottom-center graph, AP/Inventories is especially similar between the data sets. Finally, no data set is dominantly cyclical. In fact, the QFR series AP/inventory is more volatile than the corresponding ratio from Compustat (the QFR's standard deviation is .045 vs. .036 for Compustat).

\section{Conclusion: Caveats about Compustat}

One disadvantage of the Compustat data is its annual frequency, a handicap for observing firms' initial movements after a policy shock. It certainly engenders a close coincidence of tight money and the subsequent recession's onset, raising observational difficulties. For example, are customers really constrained or is it that suppliers give credit indiscriminately at cyclical peaks. We argue that customers are constrained. The TC terms are acyclical (see $\mathrm{Ng}$ et al (1999)). Furthermore, it is simply not sensible for suppliers to be more generous with trade credit at times of credit stringency. Potential customers rejected for TC during good times should also be rejected in bad times since they are then most likely to fail.

While not ideal, Compustat is acceptable for the question of this study. Its coverage of large firms is nearly as complete as the QFR's while providing greater information at the firm level. Private firms remain a concern since we expect they may be greatly influenced by business cycles. They probably rely on internal funding to a greater degree than public firms and so may be unduly affected by a lack of internal funds as sales slow unexpectedly, for example during a tight money episode. Finally, since most of the analysis of the series concern variables in ratio form, Figure A.3 shows that tests using these data sets should yield very similar results. 


\section{F I $G$ U R E 1}

AP/Sales: Small Mfg vs. Large Mfg
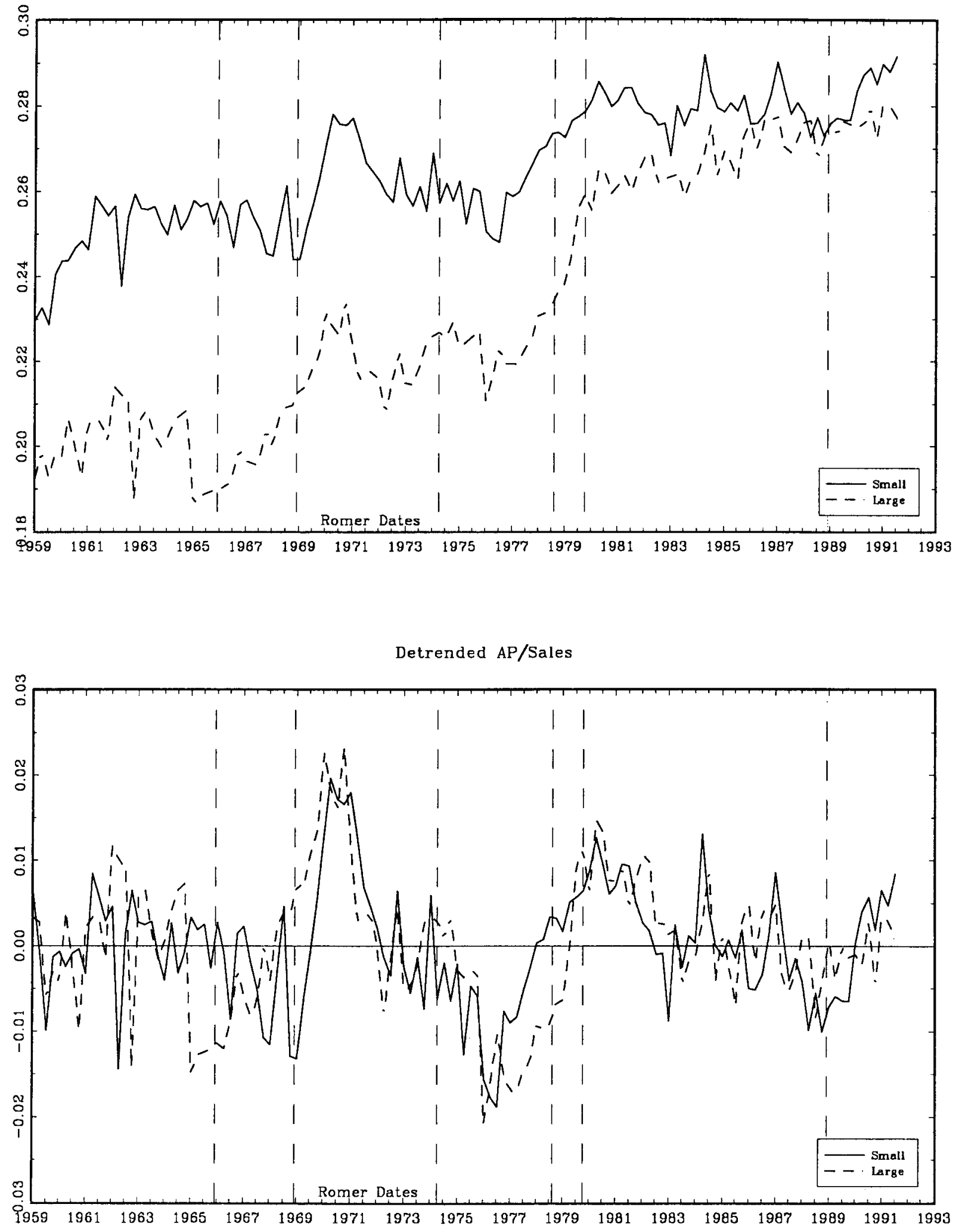
Figure 4: Average Romer Episode AP / Sales

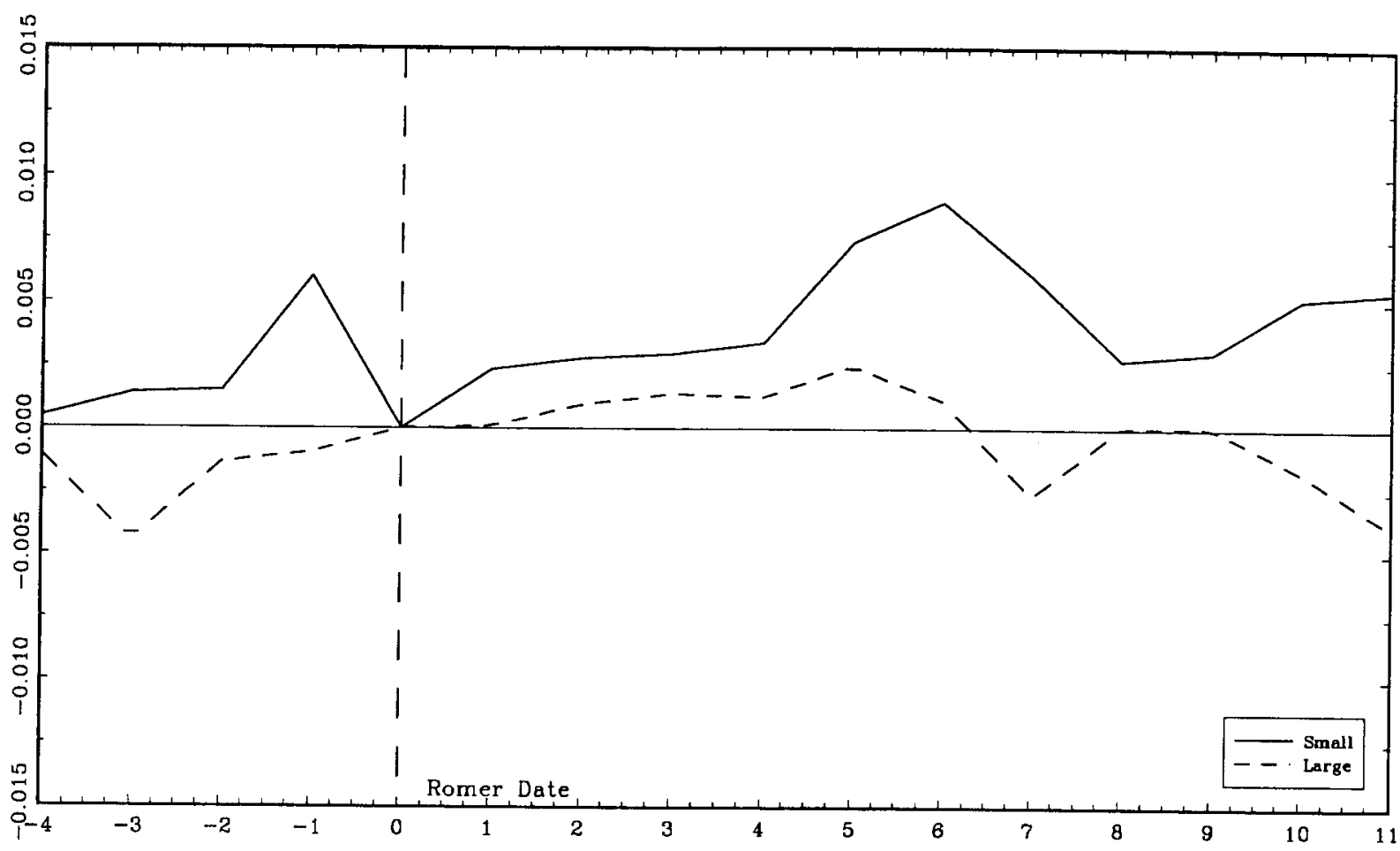

Cash / Sales

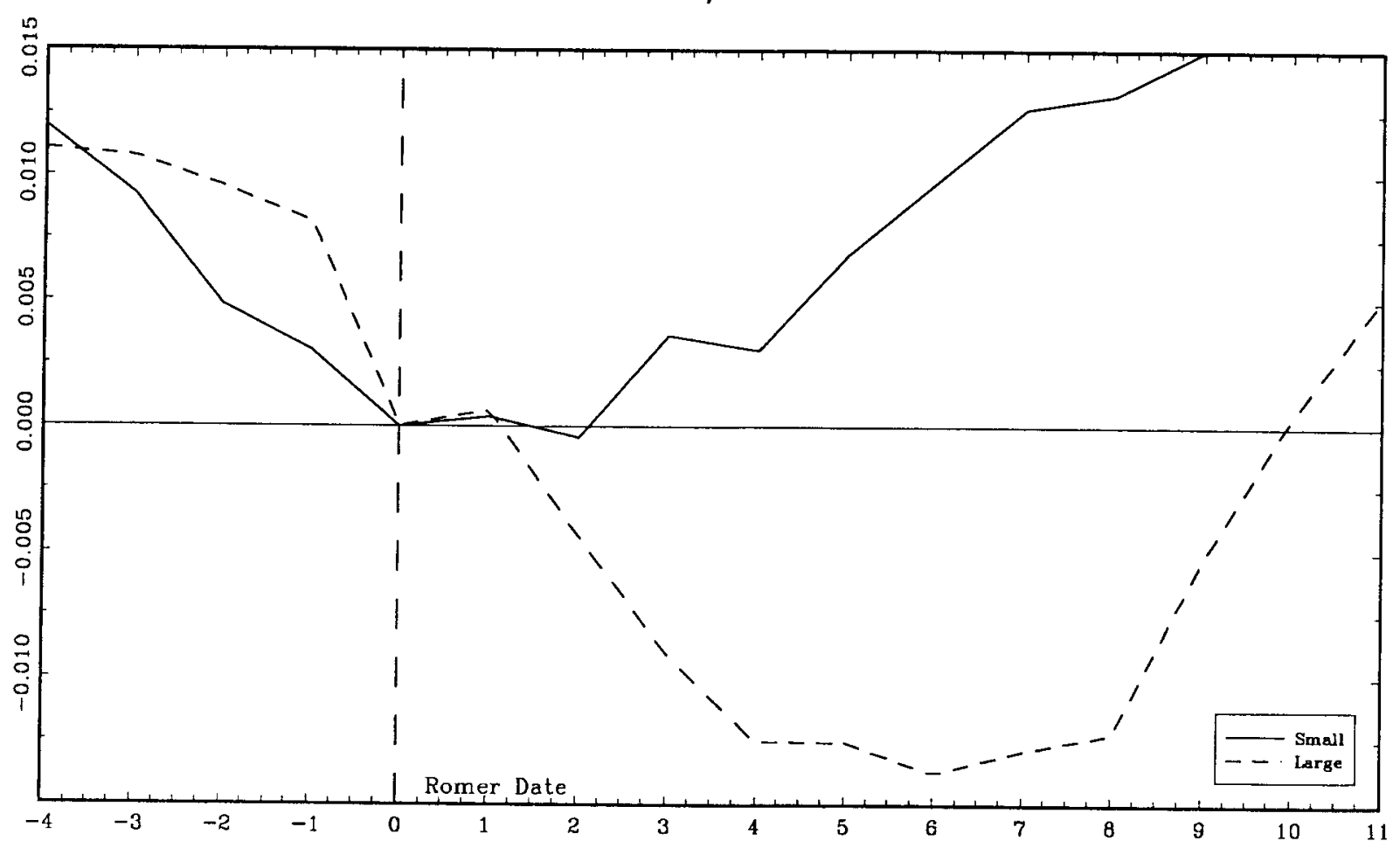




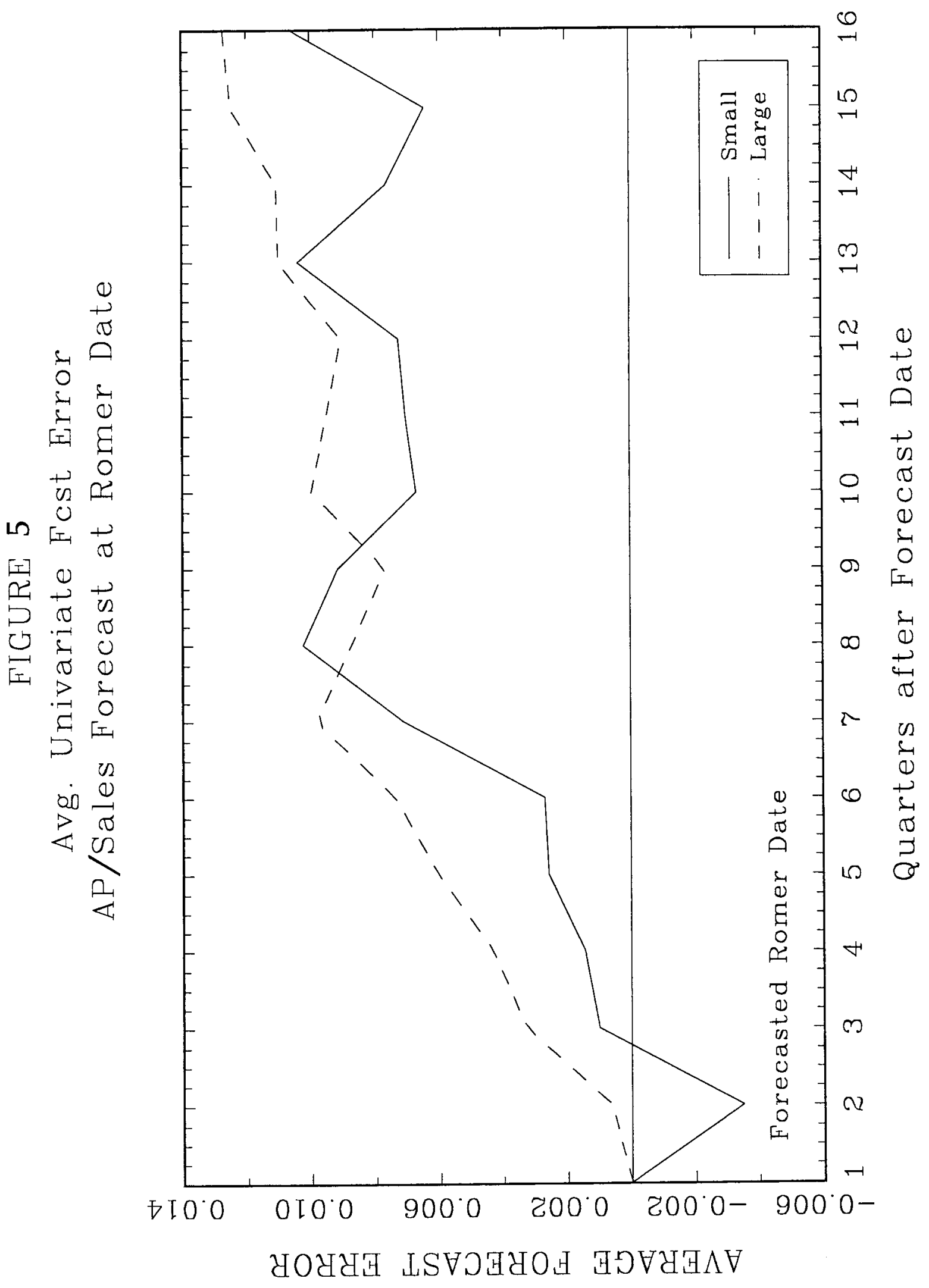


FIGURE 6
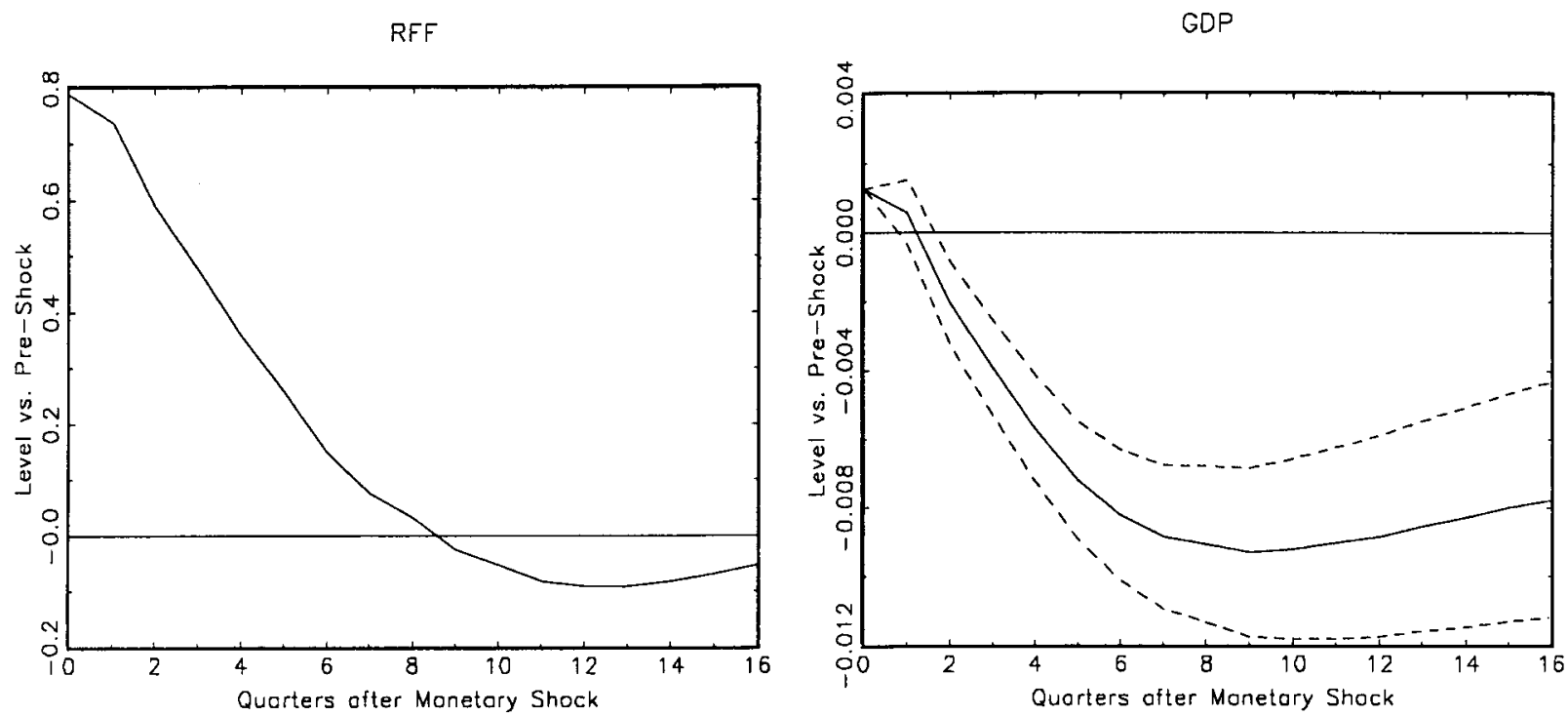

SM.IN/S

SM.C/S
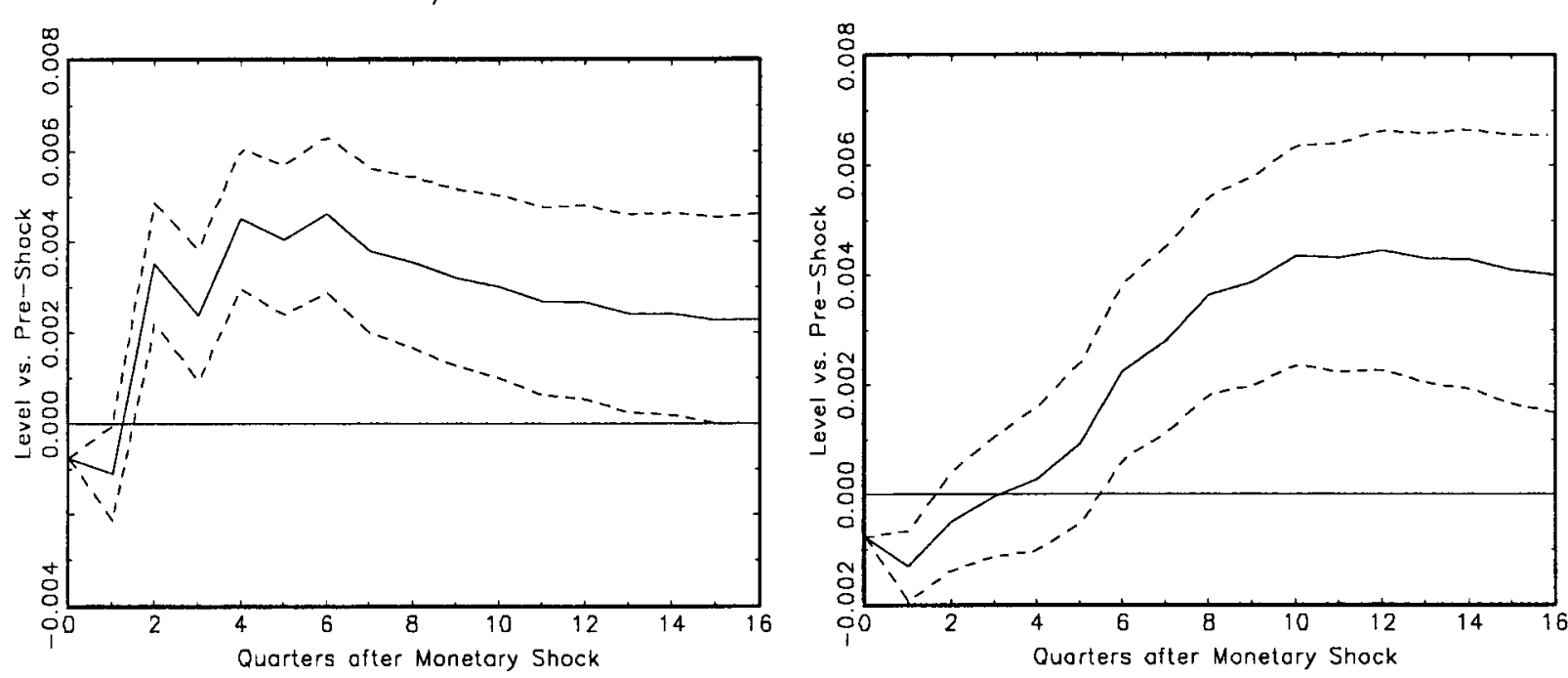

SM.AP/S

PRICE
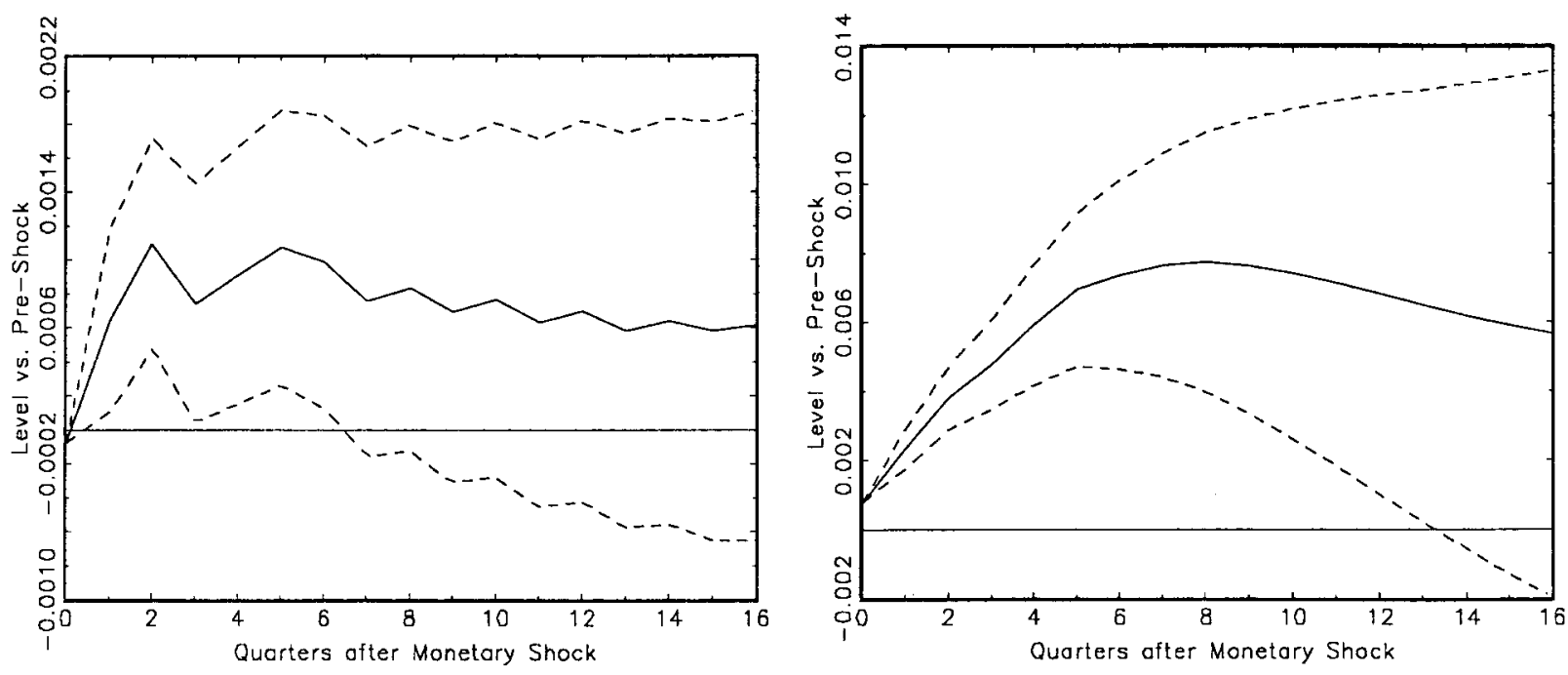


\section{FIGURE 7}

RFF

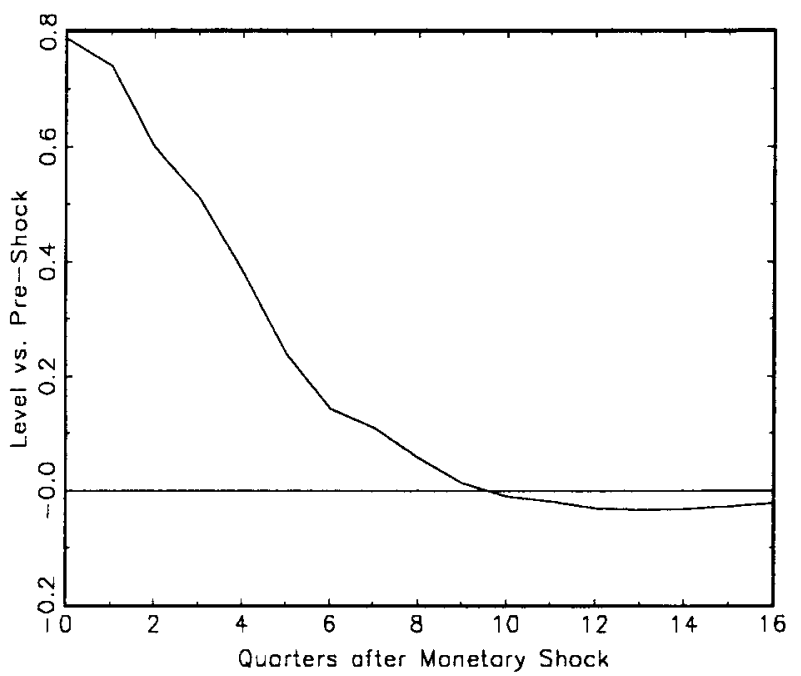

LG.IN/S

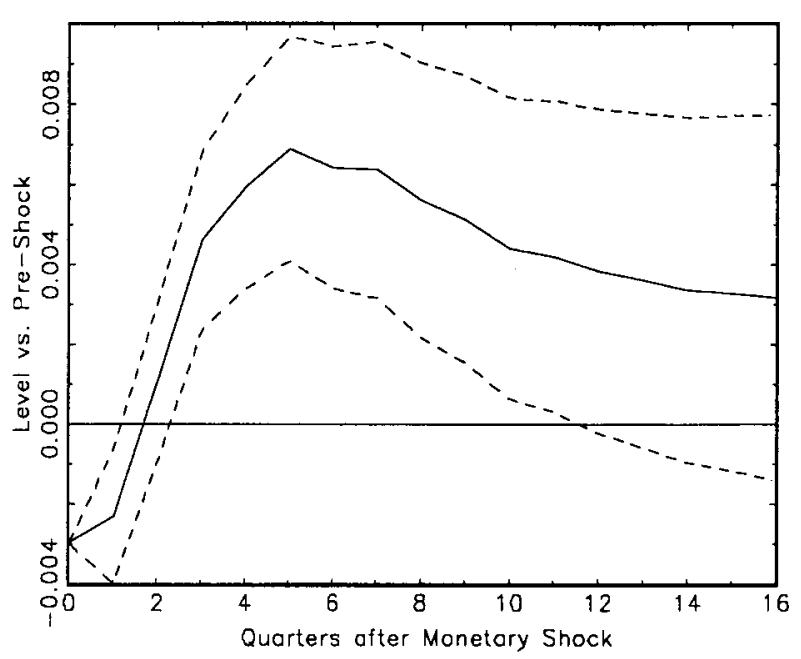

LG.AP/S

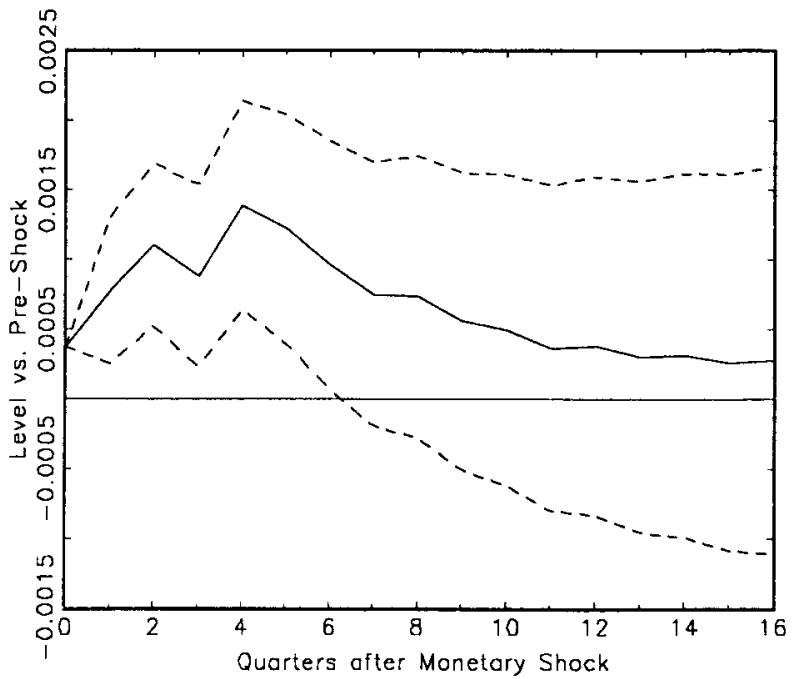

GDP

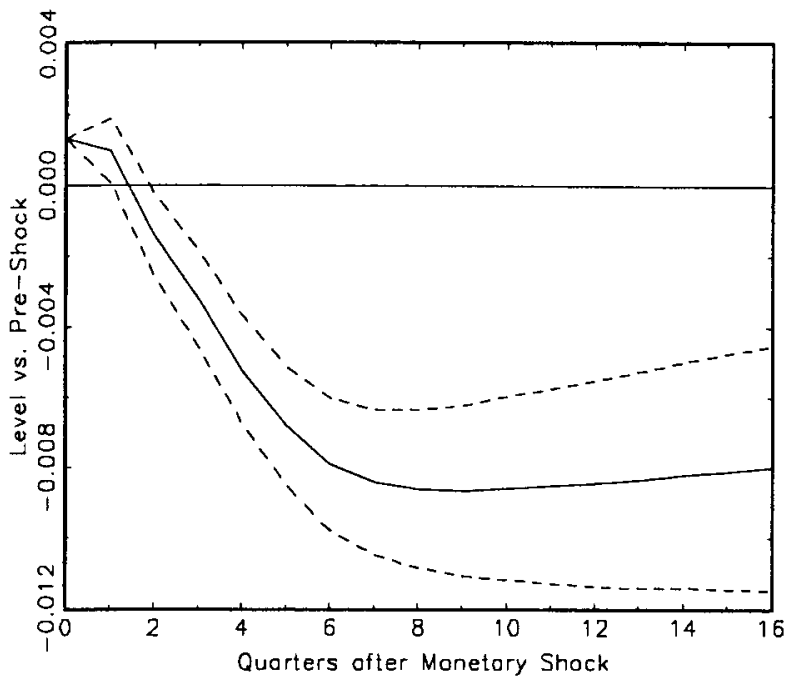

LG.C/S

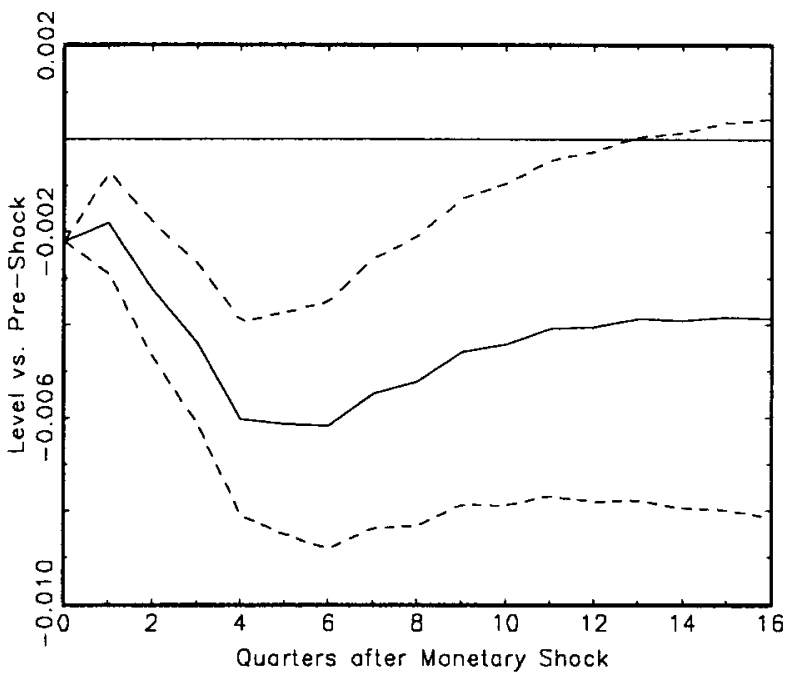

PRICE

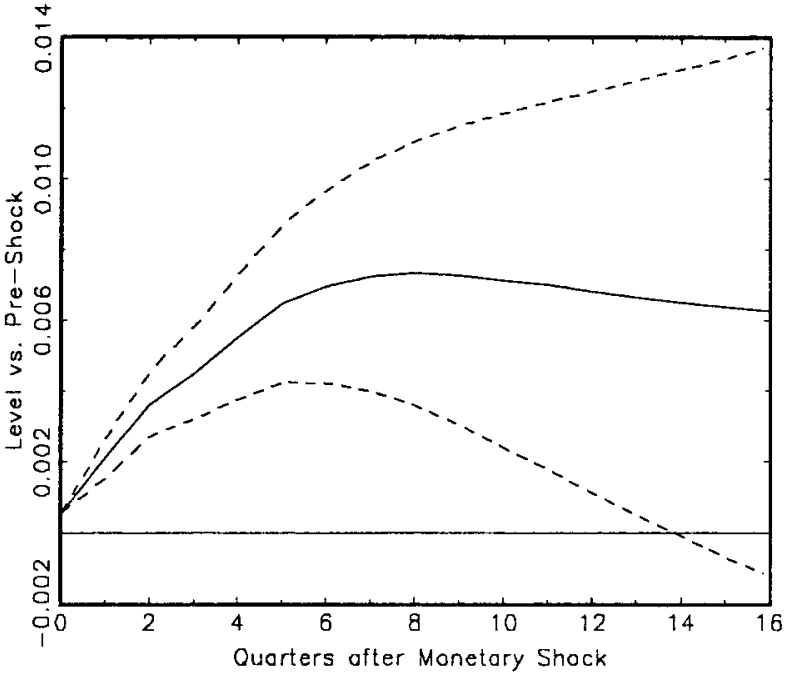


FIGURE 8
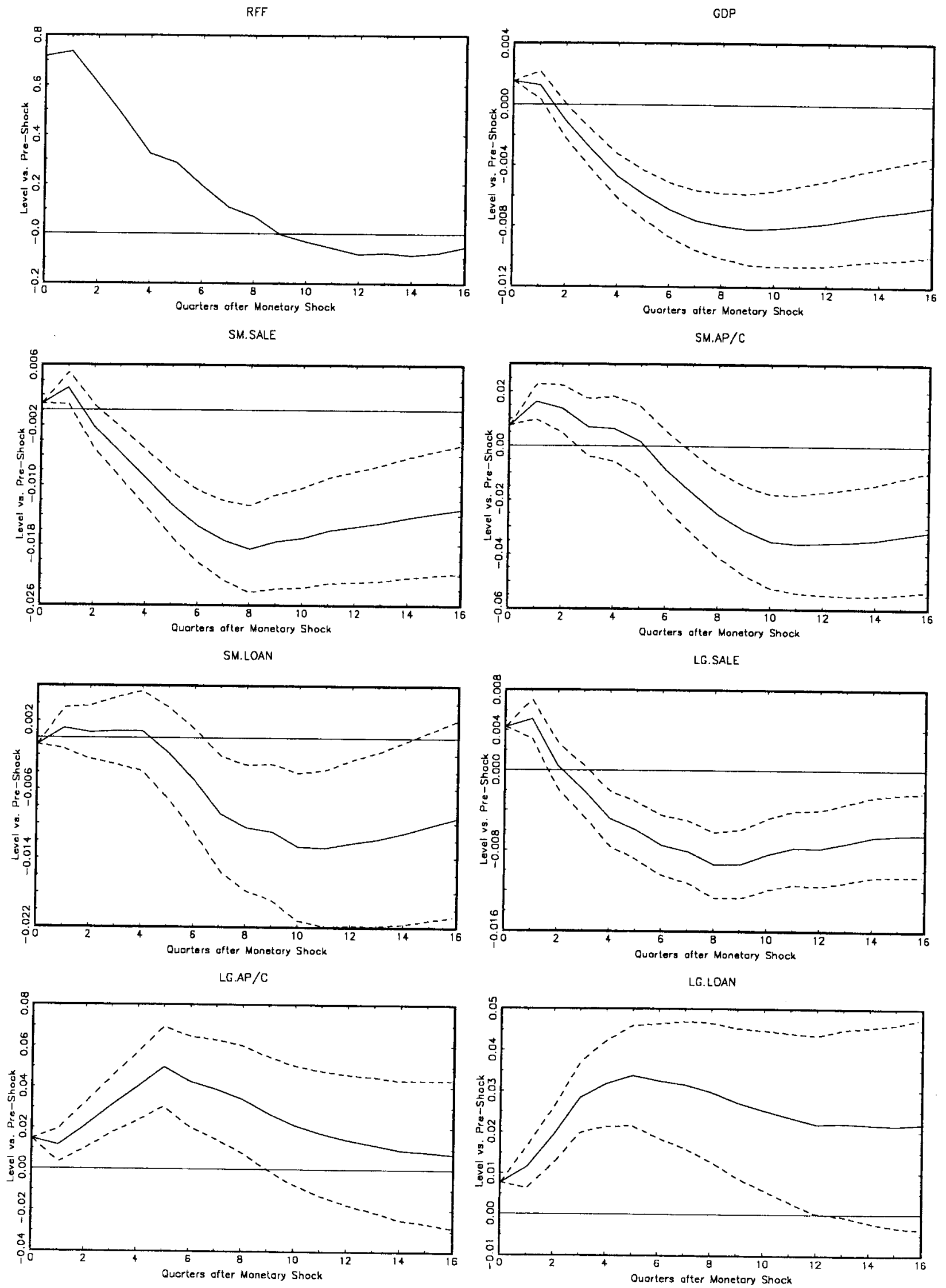


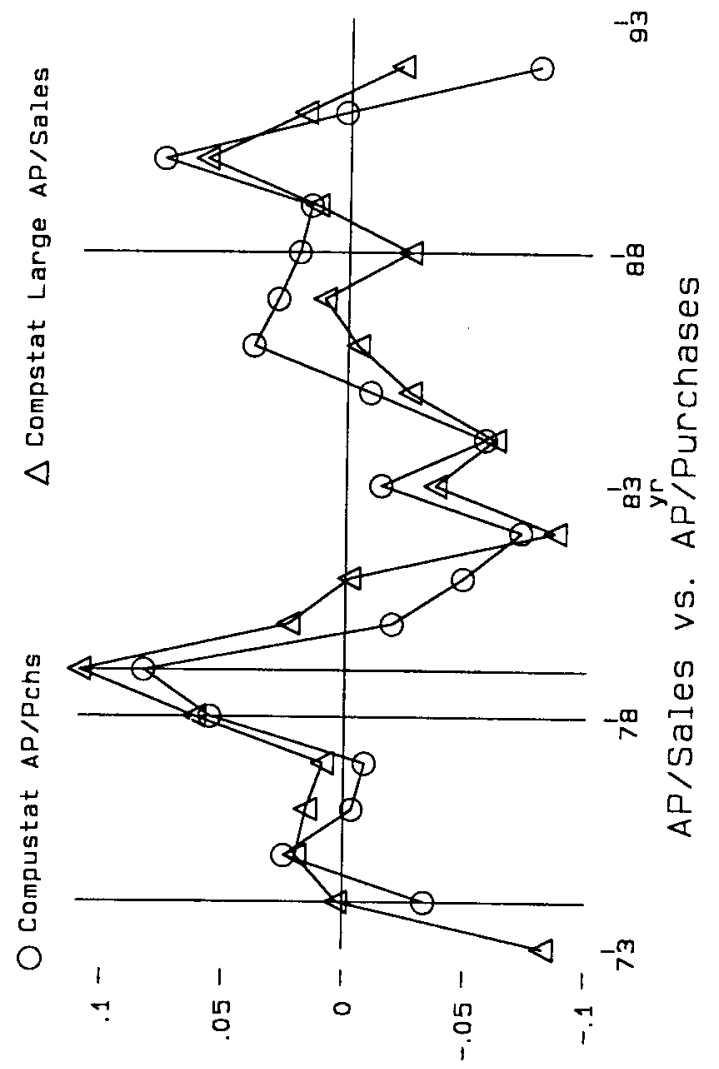

a

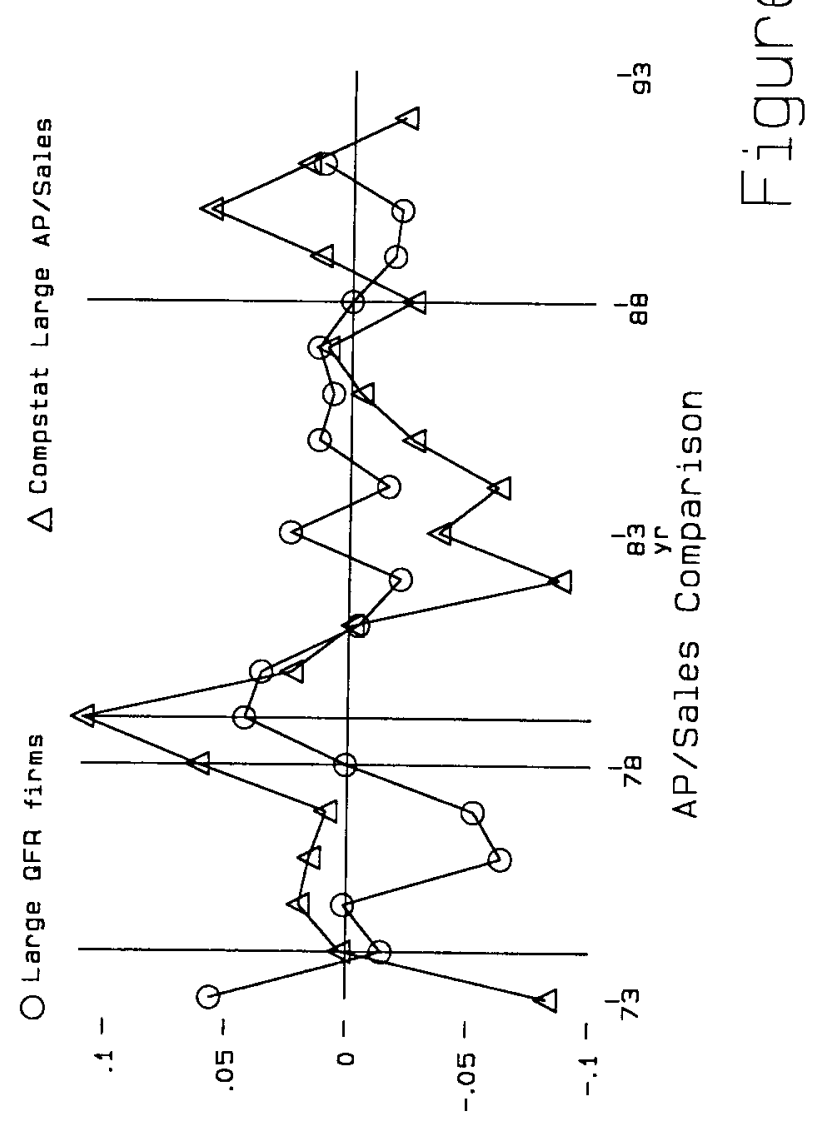




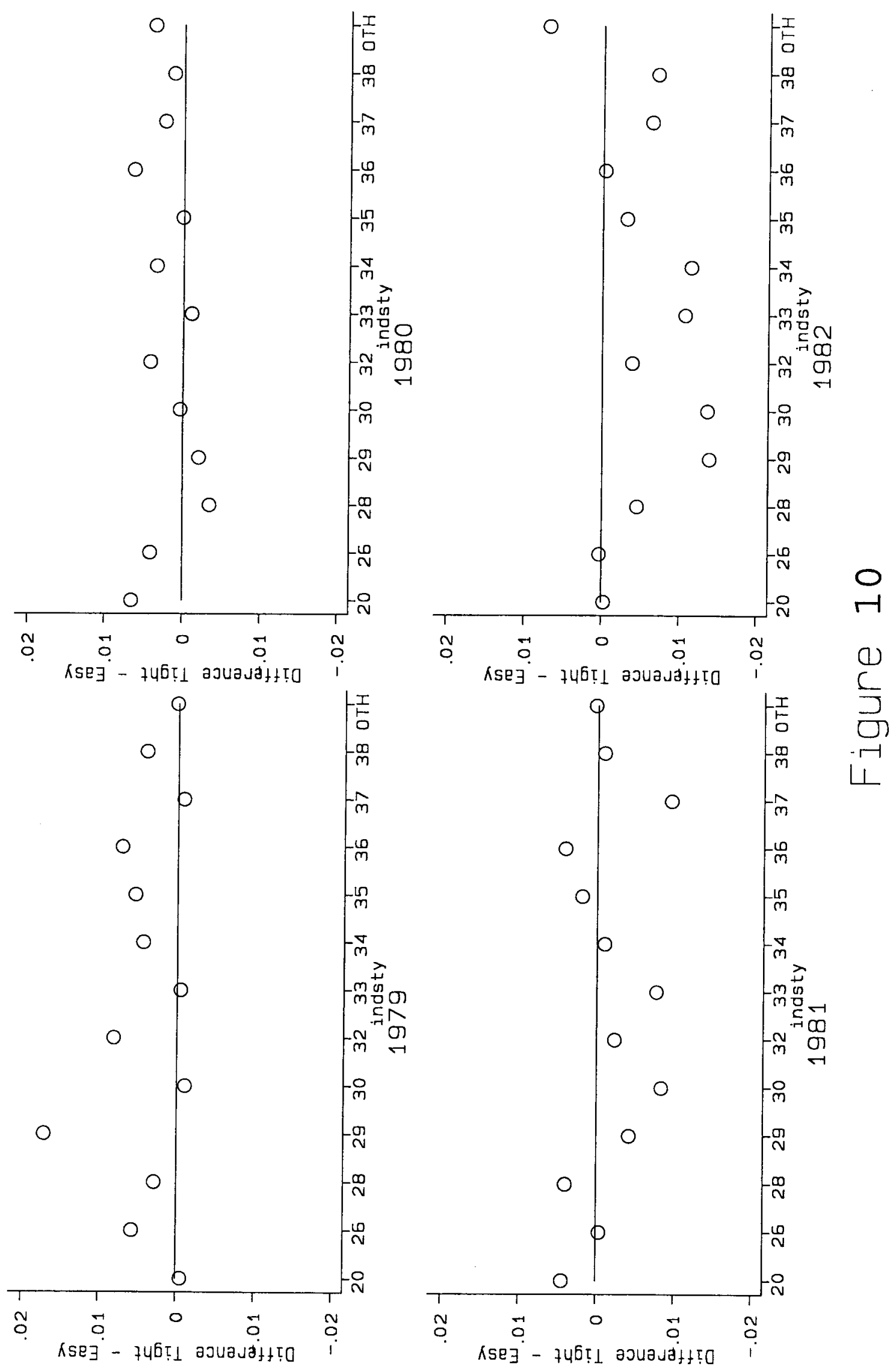




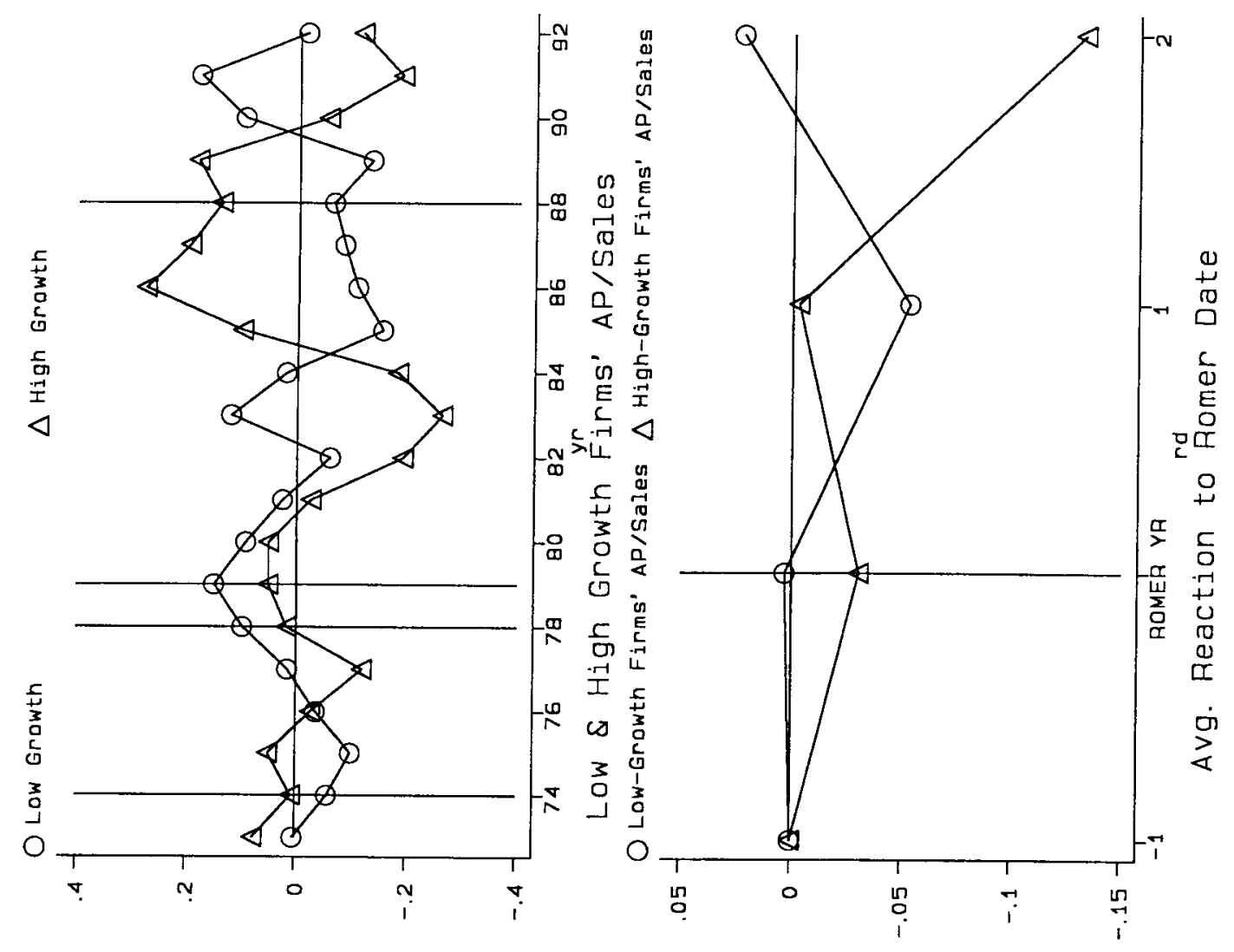

$\stackrel{0}{0}$

ฮิ

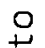

등

ㄸ

ஷं

H

(1)
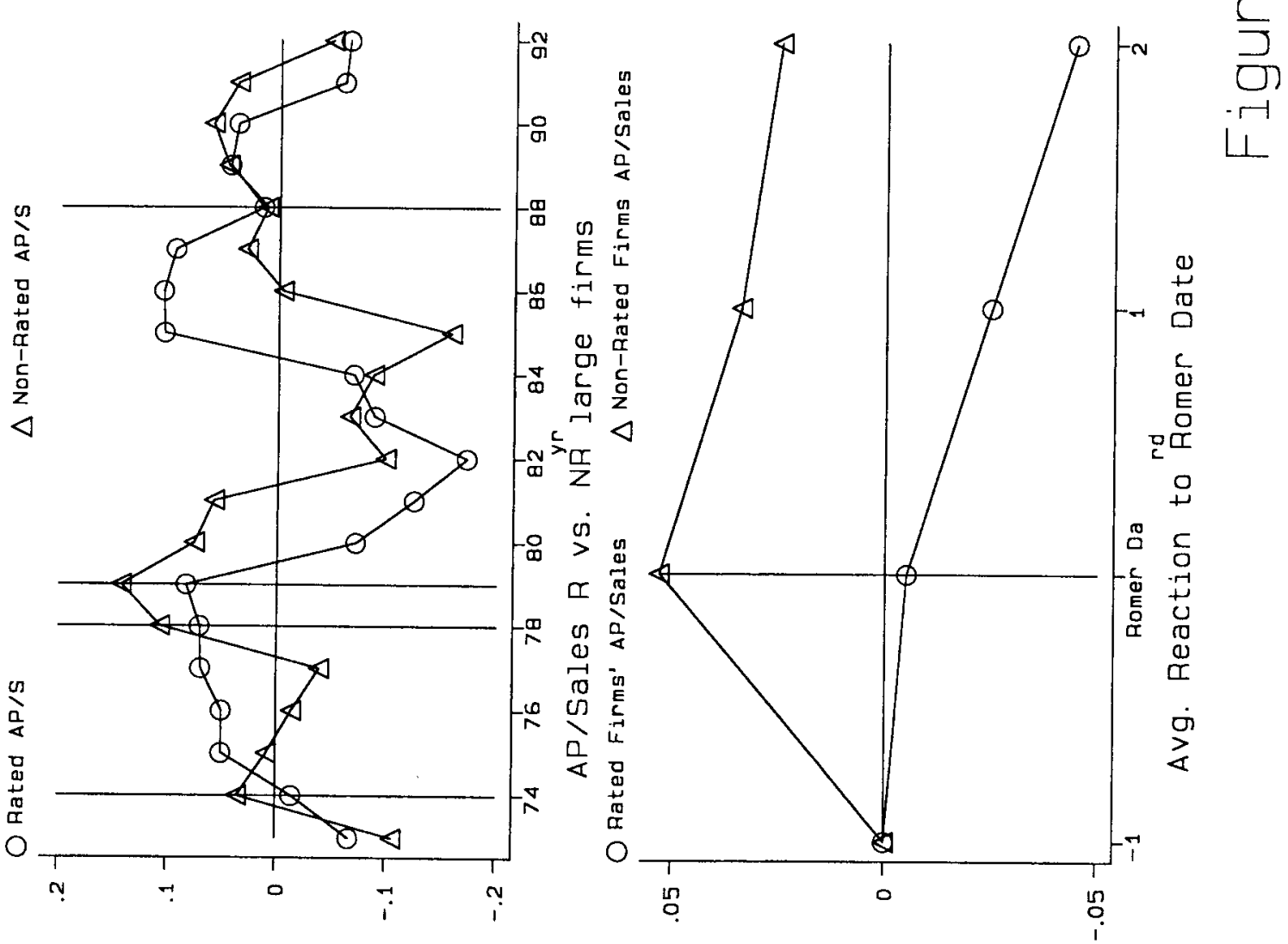

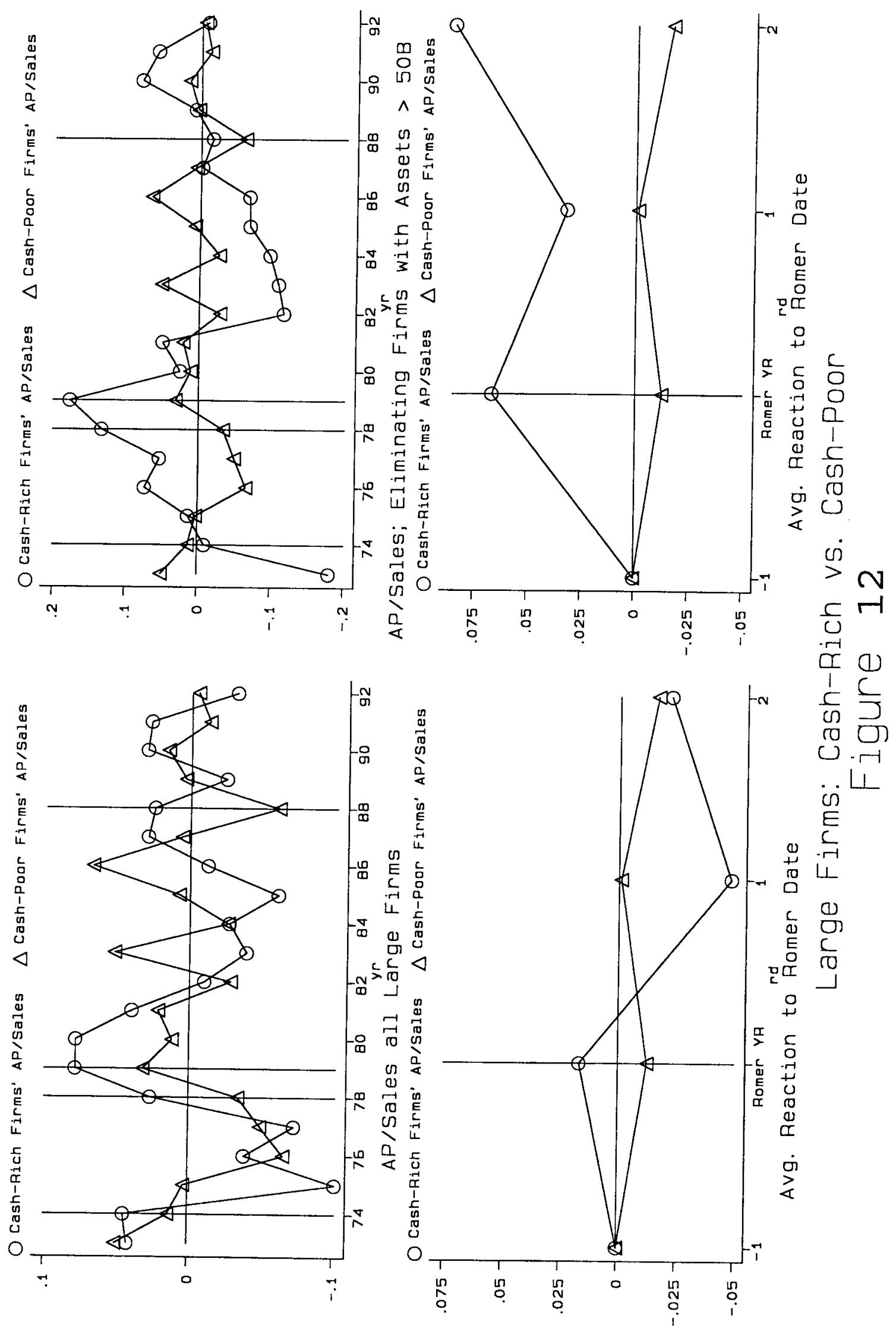

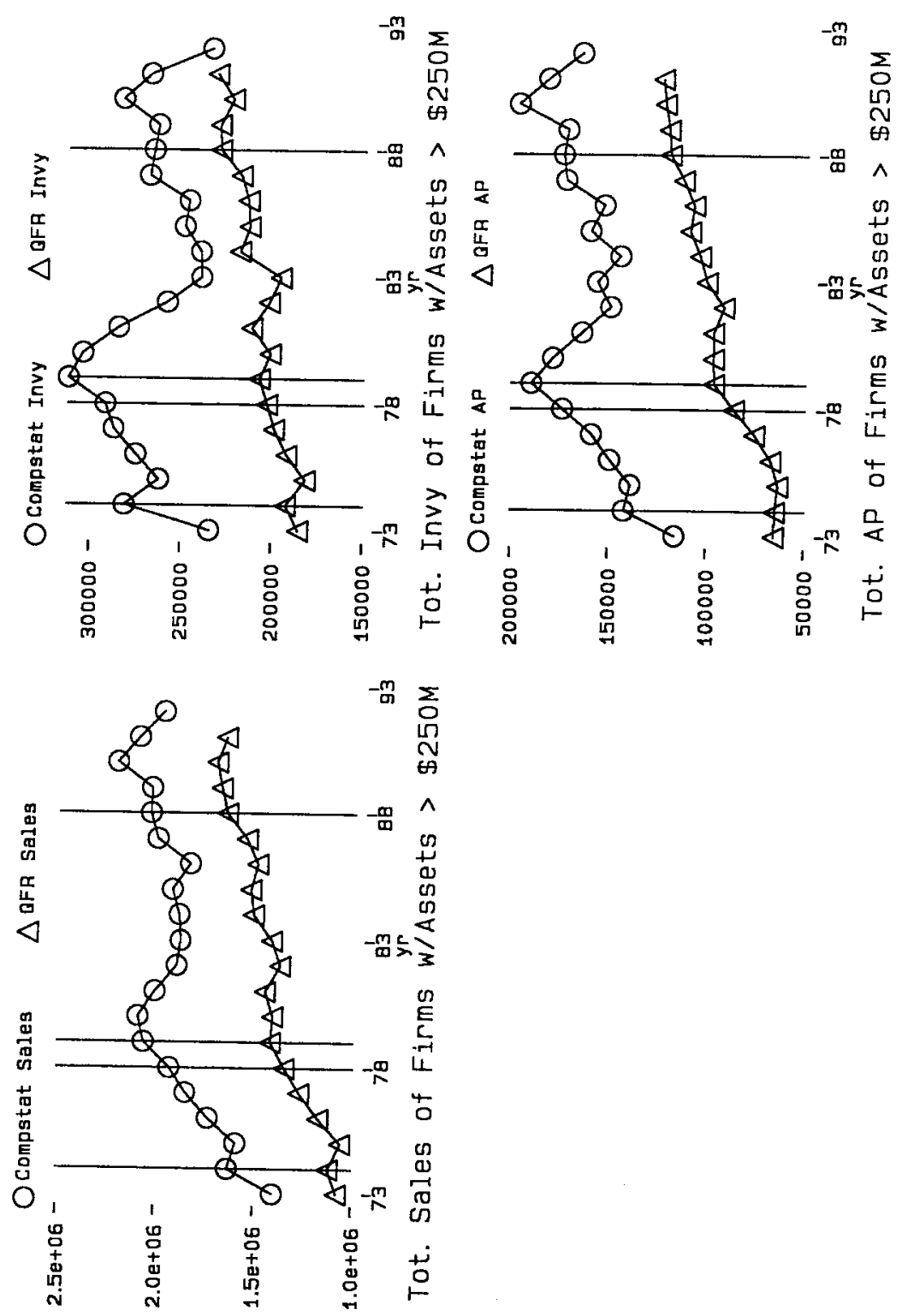

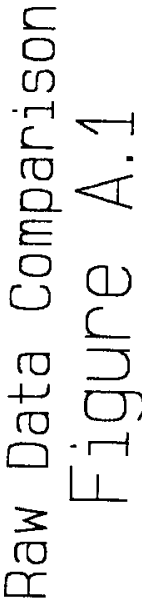

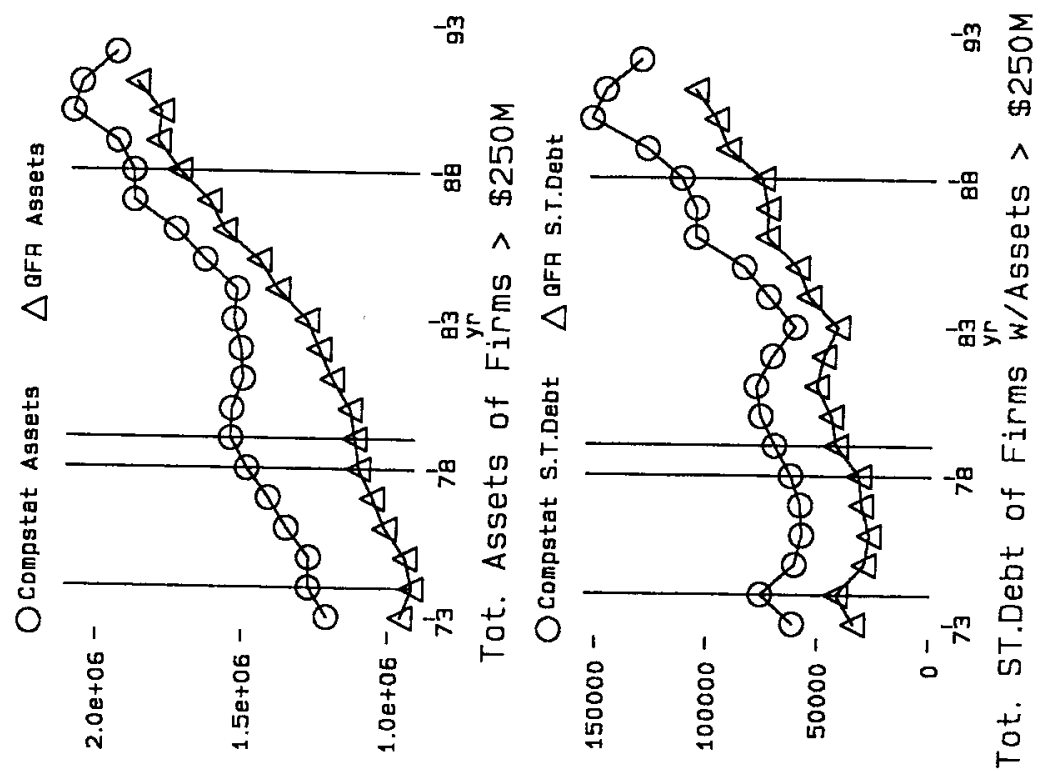




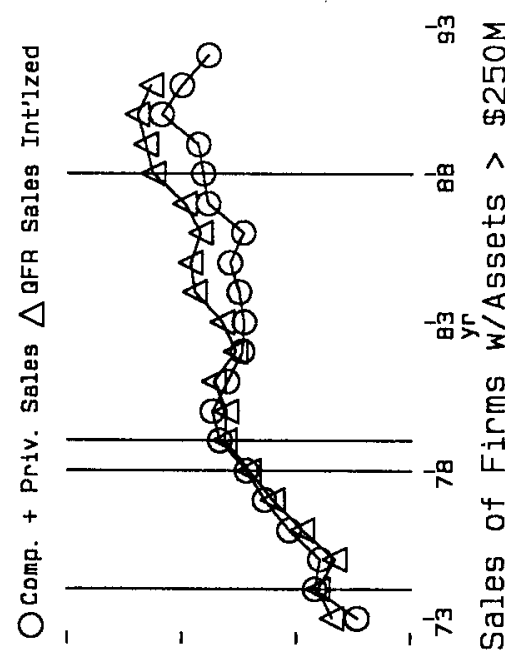

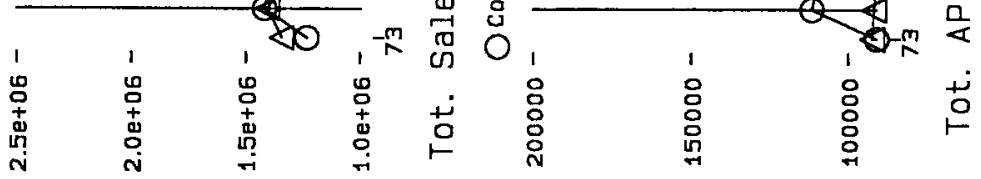
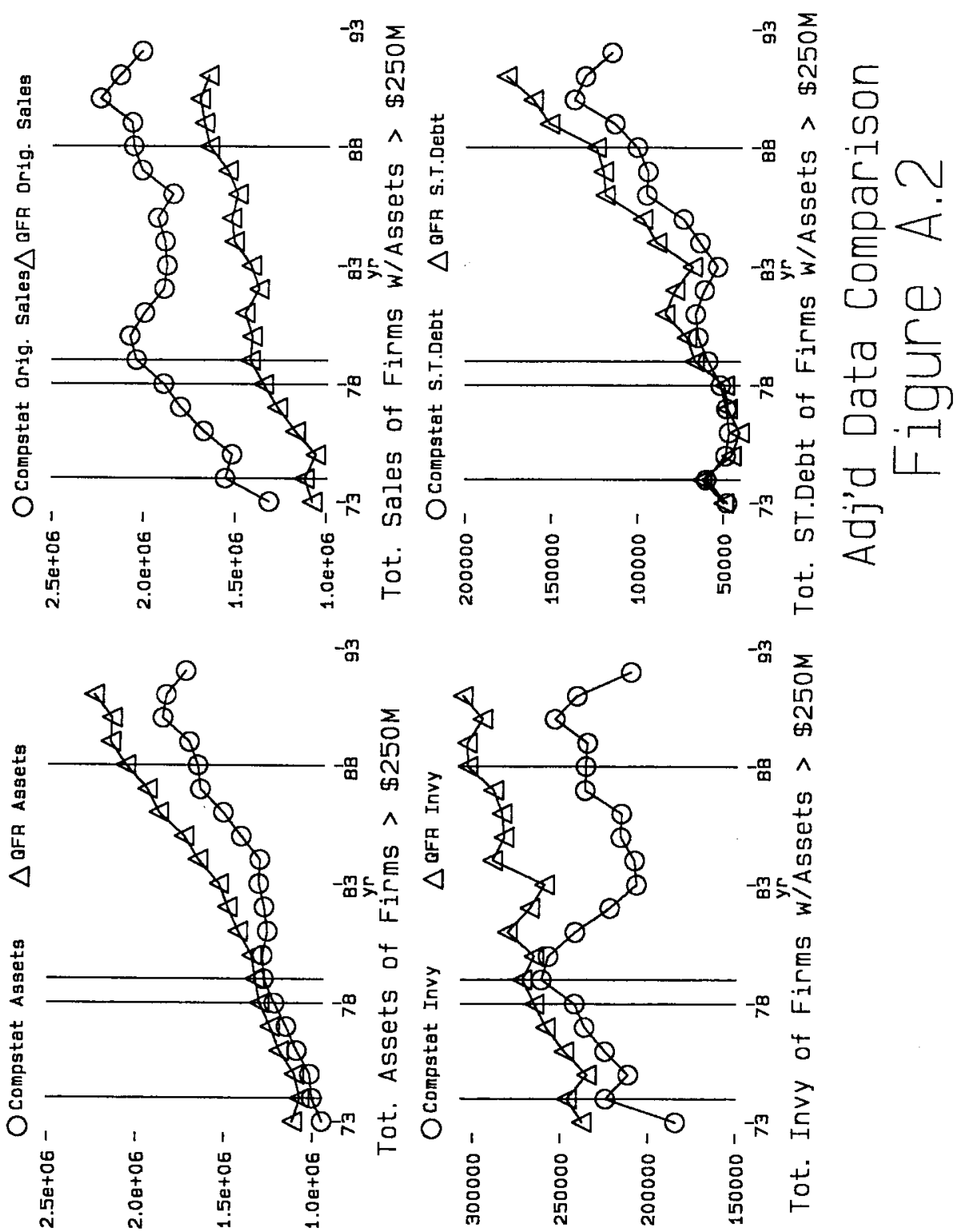

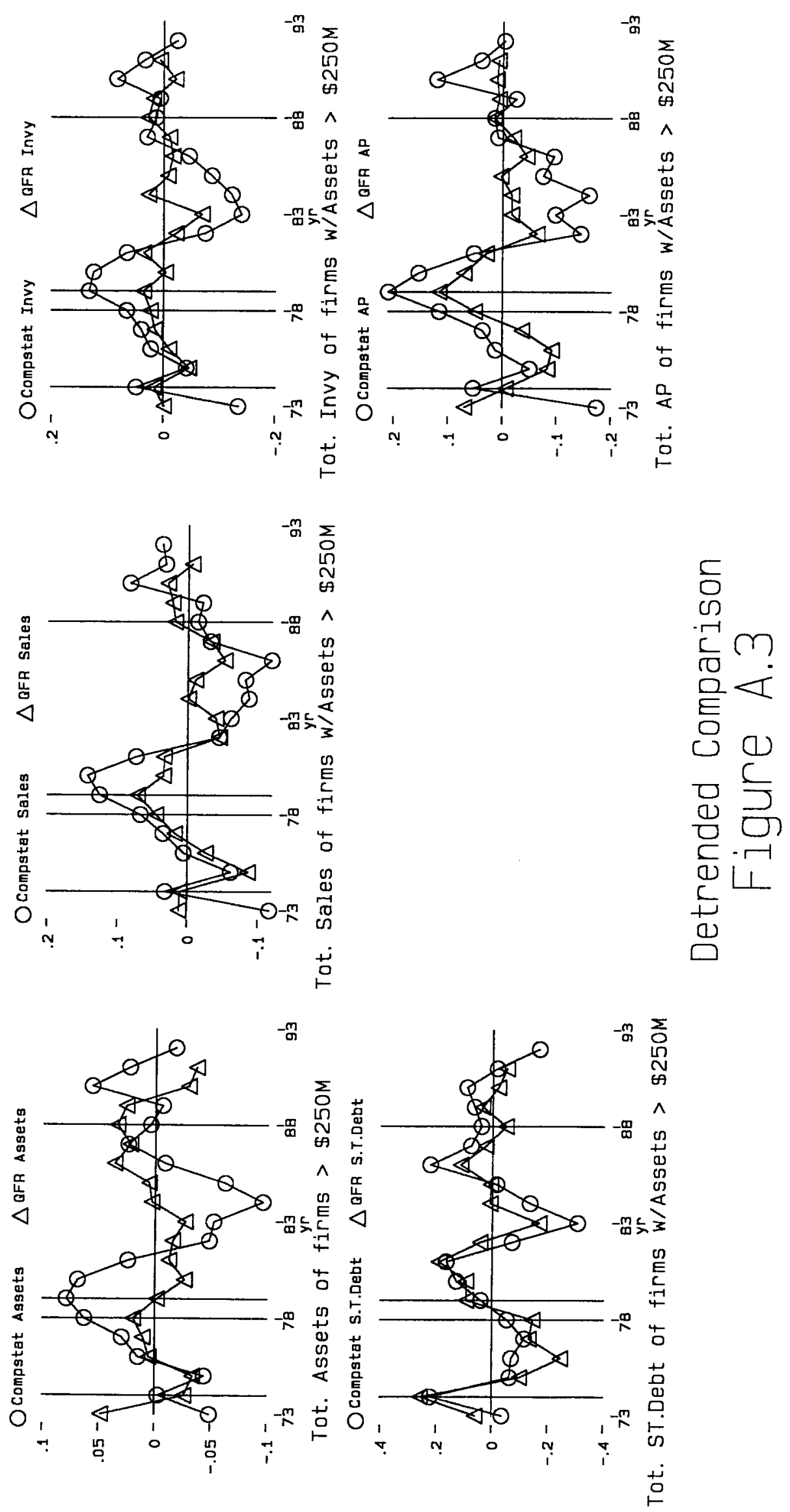

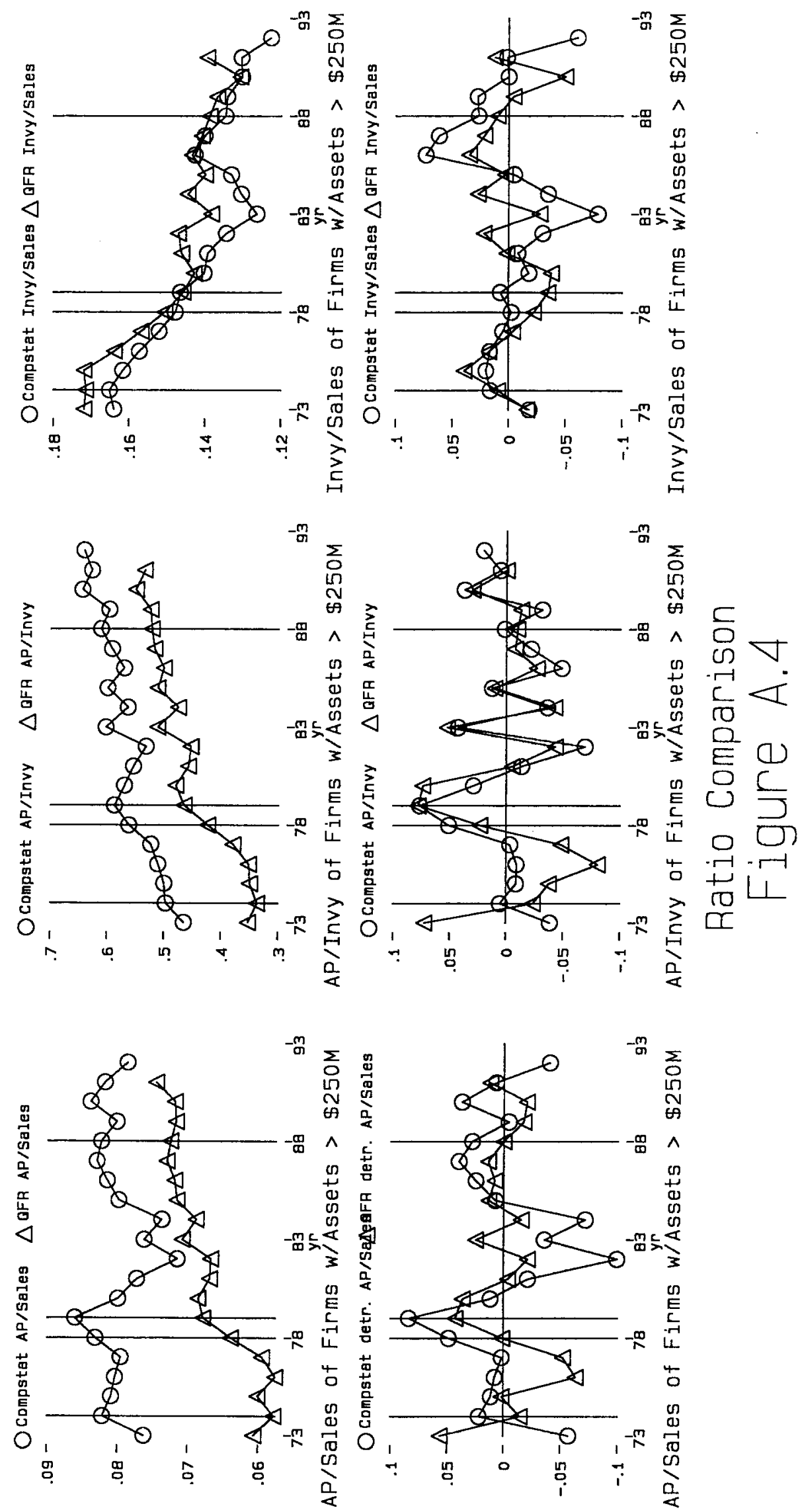